\title{
Importing under trade policy uncertainty: Evidence from China
}

\author{
Michele Imbruno \\ DIGEF, Sapienza University of Rome, Italy \\ CERDI, Université Clermont Auvergne, CNRS, France \\ GEP, University of Nottingham, United Kingdom
}

\begin{abstract}
This paper empirically explores the adjustment of imports to reductions in trade policy uncertainty (TPU), taking into account that firms may face large sunk costs when purchasing foreign goods. We investigate how product-level Chinese imports react to tariff binding arising from China's accession to the WTO, by distinguishing both country-related and firm-related margins. Our main results suggest that a decline in TPU allows access to a greater variety of foreign goods, that are also associated with higher quality. At the same time, tariff binding leads more Chinese producers and trade intermediaries to start importing, thus allowing a greater number of firms and consumers to enjoy potential gains from imports. Finally, we document heterogeneous TPU effects across firms with different ownership, as well as across products with different end use, revealing interesting insights into the context of global value chains.
\end{abstract}

Keywords: Trade policy uncertainty, Import behavior, World Trade Organization, Tariff Binding, China.

JEL: D22, F13, F14.

Acknowledgements. The author would like to thank Tobias Ketterer and all participants at the ETSG 2017 Conference (European University Institute \& University of Florence), the $11^{\text {th }}$ International Conference on the Chinese Economy (Université Clermont Auvergne), CSAE Conference 2018 (University of Oxford), and 67 ${ }^{\text {th }}$ AFSE Annual Meeting (Paris School of Economics) for their helpful comments and suggestions. This work acknowledges the support received from the Agence Nationale de la Recherche of the French government through the program "Investissements d'avenir" (ANR-10-LABX-14-01). E-mail address: michele.imbruno@ uniroma1.it. 


\section{Introduction}

It has been well established in international trade literature that firms need to pay large sunk costs in order to start exporting (Roberts and Tybout, 1997). Uncertainty over future trade policies may therefore postpone a firm's decision to enter foreign markets. One of the main principles underlying the World Trade Organization (WTO) is the predictability of national trade policies, which would imply a reduction in uncertainty, providing a better environment for making irreversible investments. An instrument used to pursue trade policy predictability is binding tariff rates on goods, through which WTO members make an enforceable commitment not to increase applied tariffs above certain ceilings (bindings). Following the Uruguay Round in 1995, developed countries exhibited a higher share of product lines with bound tariffs than developing countries (99\% versus $73 \%$ ). Moreover, it is worth noting that, despite tariff binding, relevant uncertainty can still persist if the gap between bound and applied tariff (binding overhang) is relatively high. This discrepancy is quite common amongst developing countries, whereas in developed countries, applied rate and bound rate tend to be the same.

Recent studies have already highlighted that trade policy uncertainty (TPU) may negatively affect firms' export behavior. Handley (2014) studies, theoretically and empirically, how TPU defers a firm's entry into the export market (delay) and makes firms less sensitive to applied tariff cuts (caution). In particular, using product level data from Australia during the 1991-2001 period, he estimates that the entry of foreign varieties increases by $4 \%$ if applied tariffs are reduced to zero, and by $17 \%$ if tariffs are also bound by WTO commitments. Similar findings are also confirmed in the context of/ preferential trade agreements. Using firm-level data on Portuguese exports, Handley and Limão (2015) document that the reduction of uncertainty arising from Portugal's accession to the European Community (EC) in 1986 implied a significant increase in the entry of Portuguese exporting firms into EC markets. 
This paper aims to empirically explore how trade policy uncertainty may influence firms' import behavior - rather than export behavior - given that previous works had documented that firms also have to face large sunk costs in order to start importing (Andersson et al., 2008; Kasahara and Rodrigue, 2008; Kasahara and Lapham, 2013). For example, they need to search for foreign suppliers, check whether foreign inputs can be easily integrated into the current production process, learn customs procedures, eventually acquiring import licenses, etc. These costs tend to be higher when the distance from trade partners is considered, in terms of physical distance, but also language, culture, legal system, and so on. ${ }^{1}$

Moreover, we expect the discussions above on TPU and firms' export decisions to be even more pertinent for firms' import decisions since, by incorporating foreign intermediate inputs, they can imply irreversible changes in production technology. Indeed, while exporting only indirectly affects production by means of learning-by-exporting and changing demand, importing directly influences the production system and productivity (Zhang, 2017). In addition to static gains from using foreign inputs, due to quality and variety effects on current productivity (Amiti and Konings, 2007), firms may benefit from dynamic gains due to import experience, implying changes in future productivity (Zhang, 2017). Indeed, importing allows firms to directly change their knowledge about production, through technical support from their foreign suppliers, or to indirectly improve their know-how, through larger investments in R\&D. ${ }^{2}$ Import decision may also be characterized by partial irreversibility because of frictions that can hinder adjustments in firms' sourcing decisions, such as time delays in negotiating with

\footnotetext{
${ }^{1}$ The sunk fixed costs of importing and exporting are not mutually exclusive. However, if a firm wants to start both export and import activities, it needs to pay the sunk costs of two-way trading, which could be relatively small compared to the sum of the sunk costs of exporting and importing, due to the complementarity between the two trade activities (Kasahara and Lapham, 2013).

${ }^{2}$ Boler, et al. (2015) document a strong complementarity between R\&D investments and imports, showing that either R\&D incentive policy or input trade liberalization lead firms to increase both innovation and international outsourcing.
} 
new input suppliers, frictions in matching with foreign suppliers, or harmonization with other input or investment decisions (Ramanarayanan 2017). ${ }^{3}$

Given that when making an import decision, a firm needs to take into consideration that international outsourcing and related trade reforms generate both short-term and long-term effects, some costs of starting import activities are sunk, as well as the firm's import status cannot easily be changed in every period, import behavior may therefore be dramatically affected by trade policy.

Using Chinese (ordinary) trade transaction data during the period 2000-2006, we explore how tariff binding, arising from China's accession to the WTO in December 2001, affects imports at the product level. We first make a country-related analysis, differentiating the product-level import value between the number of country-varieties (country-extensive margin) and the average imports per country-variety (country-intensive margin), focusing in particular on the on the country-extensive margin to verify whether a reduction in Chinese TPU positively affects the entry of new foreign varieties into China. In line with Handley (2014)'s findings, our results suggest that, subsequent to tariff binding, the Chinese economy has been able to access a greater range of foreign varieties, especially from developed countries, which are typically associated with high-quality. However, we find different results across product groups distinguished according to their end use, suggesting that whereas the decisions made by worldwide firms to supply final and intermediate goods to China tend to be delayed by China's TPU, their decisions to supply capital goods are actually brought forward. Moreover, while consumers benefit from a wider range of all foreign final varieties, firms enjoy access to both a greater variety and higher quality of intermediate varieties.

\footnotetext{
${ }^{3}$ For example, using firm-level data from Chile, Kasahara (2004) finds that an increase in the import-to-domestic ratio of intermediate inputs is associated with an increase in physical capital investments, interpreted as a technology upgrading.
} 
Next, we carry out a firm-related analysis, differentiating the product-level import value between the number of importing firms (firm-extensive margin) and average imports per firm (firm-intensive margin), focusing more closely on the firm-extensive margin to see whether a reduction in Chinese TPU positively affects the entry of new Chinese firms into the import market. We document that tariff binding leads more firms to start importing a given product. This effect is confirmed for both producers and trade intermediaries, and suggests that a larger number of Chinese manufacturing firms are able to import foreign intermediate inputs, directly or indirectly, and therefore benefit from potential productivity gains due to TPU reduction. In other words, it seems that TPU tends to delay a firm's decision to import intermediate inputs. At the same time, we also find that TPU would hasten a firm's decision to import capital goods. Finally, it appears that tariff binding pushes more foreign-owned manufacturing firms located in China to import intermediate inputs under the ordinary trade regime - through which they are not obliged to re-export, as they are with the processing trade regime - and more foreignowned intermediaries to be involved in importing final varieties. These results suggest that FDI in China is starting to become relatively more market-seeking than resource-seeking following Chinese TPU reduction: i.e. foreign multinationals tend to relocate the downstream stages of global value chains relatively more than the upstream stages in China.

These findings are robust when considering the binding gap, when excluding the foreign TPU effect, and when exploring either the import frequency of products or the import reaction to applied tariff cuts following tariff binding. Similar conclusions are reached when replicating the firm-related analysis at both the product/country level and the firm/product/country level.

This work is complimentary to two recent studies on trade policy uncertainty and export behavior in China, carried out respectively by Handley and Limão (2017) and Feng, et al. (2017). Handley and Limão (2017) theoretically show that TPU reduction can lead more firms to start exporting, and a larger number of incumbent exporters to upgrade their technology, 
implying an increase in both the number of exporters and average exports per firm. Then, using 6-digit product level data on Chinese exports to the US, they show that uncertainty reduction arising from China's accession to the WTO in 2001 implied a significant growth in Chinese exports to the US market in the period 2000-2005. Feng, et al. (2017) also study, theoretically and empirically, how Chinese exports to the US are affected by a reduction in trade policy uncertainty following China's accession to the WTO. More specifically, by using Chinese firmproduct level data, they show that TPU reduction has allowed the entry of new firms into the export market, and led to the exit of some incumbent exporters, as well as demonstrating that, compared to export-stoppers, export-starters are associated with lower prices and higher quality. ${ }^{4}$ Unlike these two studies, we focus on Chinese firms' import reactions to the reduction of domestic TPU in a context of multilateral trade, rather than concentrating on Chinese export reactions to foreign TPU reduction in that of bilateral trade (US-China), through the exploitation of the time-varying binding status of product lines, rather than the binding overhang. It is worth noting that while our country-related results approximately confirm their findings, i.e. that a foreign country's TPU reduction leads more domestic varieties, mostly associated with higher quality, to enter the international market, our firm-related analysis provides interesting new insights from an import perspective in the context of global value chains. ${ }^{5}$

The rest of the paper is organized as follows. Section 2 describes the data used, also giving information about the context. Section 3 sets up the empirical strategy for exploring product

\footnotetext{
${ }^{4} \mathrm{Mau}$ (2017) shows that a reduction in US tariff uncertainty arising from China's accession to WTO also positively affected China's exports to the European Union.

${ }^{5}$ Pierce and Schott (2016) already provide some evidence, amongst other results, that a reduction in domestic TPU can determine an increase in the number of importing firms at home, in addition to an increase in the number of exporting firms abroad. However, their work mainly focuses on the employment effects of a one-time change in domestic TPU in a developed country in the context of a bilateral trade relationship. In particular, they document that a reduction in the US's TPU with regard to Chinese imports, arising from China's accession to the WTO, led to relevant significant employment losses in the US, in addition to higher imports from China.
} 
level linkage between imports and trade policy uncertainty. Section 4 discusses the results, and Section 5 provides conclusive remarks.

\section{Data}

The analysis is based on a balanced panel of 4,090 6-digit HS manufacturing product lines during the period of 2000-2006. Import data are from the database of Chinese Customs Trade Statistics (CCTS), managed by the General Administration of Customs of China; applied tariff data are from the World Bank's World Integrated Trade Solution (WITS) database; and bound tariff data are from WTO's Consolidated Tariff Schedules database (CTS). We have also included data on non-tariff trade barriers (NTBs) from China's Protocol of the WTO accession available on the WTO's website.

The CCTS database contains all China's monthly trade transactions, but we focus only on imports. For each firm/product/country-level import flow, the database provides information on total value, FOB unit value (in US dollars), quantity, and trade regime. It is also possible to distinguish firms according to their macro-sector status - i.e. between producers and trade intermediaries - and ownership - i.e. between foreign-owned (FORs) and domestic-owned firms, which are further split into state-owned (SOEs) and private-owned companies (DPRIVs). Since the main purpose of the paper is to investigate how tariff binding affects imports at the product level, we dropped all observations concerning a specific trade regime different from the ordinary trade regime and collapsed the data at the 6-digit HS product-year level. ${ }^{6}$ Subsequently, the import data were merged with product-level data on applied tariffs, bound

\footnotetext{
${ }^{6}$ Notice that we focus on product-level ordinary import transactions that are directly subject to applied tariffs, and therefore to our TPU measure (tariff binding), rather than on firm-level ordinary or processing import status ( $\mathrm{Yu}$, 2015; Manova and Yu, 2016; Brandt and Morrow, 2017). Thus, when accounting for the firm-extensive margin within each product, the number of firms involved in ordinary import transactions can refer to either pure ordinary importers (firms importing 100\% under ordinary trade regime) or mixed ordinary importers (firms importing under both ordinary trade regime and other regimes, including the processing trade regime).
} 
tariffs, and NTBs, and all observations where applied tariff was missing were dropped. Finally, we restricted our sample to the balanced panel of product lines.

\subsection{Product-level Imports}

Table 1 shows that, on average, a product exhibited an import value of around 17.3 USD million in 2000, and was imported from 13 countries (country-extensive margin) with an average import value per country around 1.1 USD million (country-intensive margin), as well as by 104 Chinese firms (firm-extensive margin), with an average import value per firm around 0.34 USD million (firm-intensive margin). It is worth noting that almost all source countries were WTO members, and that two-thirds of origin-countries were from the OECD area. Moreover, about two-thirds of importing firms were producers, mostly foreign-owned and state-owned firms, whereas the remaining share consisted of trade intermediaries, almost exclusively state-owned firms.

During the period 2000-2006, the product-level import value drastically increased (by about 38.6 USD million), due to both country-related intensive and extensive margins. More specifically, while the number of non-WTO source countries remained unchanged, a product was on average imported from an additional six WTO members, of which three from developed countries and the remaining three from developing countries. Considering that goods from advanced economies are associated with higher quality, these patterns reveal an increase in variety of both high-quality and low-quality goods. ${ }^{7}$ Indeed, using Chinese trade transaction data during the period 2000-2006, as we have in the current study, Bas and Strauss-Kahn (2015) document that input trade liberalization led to quality upgrading of imported intermediate

\footnotetext{
${ }^{7}$ Previous empirical studies also make a plausible, although extreme, assumption that products from developed countries are more likely to be associated with higher quality compared to those from developing countries (e.g. Lööf and Andersson, 2010; Bas and Strauss-Kahn, 2014).
} 
inputs, providing evidence that, subsequent to input tariff cuts, firms import more input varieties from developed countries, which are on average associated with a higher price.

Import growth was also due to an increase in both firm-related intensive and extensive margins. In particular, the increase in the number of importing firms regarded relatively more producers than intermediaries. More specifically, on average, a product seems to be imported by a larger number of private-owned producers (especially FORs) and private-owned trade agents (almost exclusively DPRIVs), and a smaller number of state-owned trade agents. These changes confirm that China's accession to the WTO allowed both producers and final consumers located in China to access foreign varieties more easily.

\section{Table 1 [Here]}

When distinguishing products across different end-use categories, we notice that the values documented above concern relatively more intermediate goods, since they represent the majority of product lines. ${ }^{8}$ However, similar patterns are found for both final and capital goods, with slightly different magnitudes. Thus, following China's accession to WTO, more privateowned manufacturers located in China became able to access directly or indirectly - through the increasing presence of private trade intermediaries - a greater variety of both high-quality and low-quality foreign inputs. This means that they had the opportunity to enjoy potential productivity gains and quality upgrading effects, implying an increase in consumers' welfare. At the same time, Chinese consumers also obtained greater access to foreign final varieties of both high- and low-quality goods, implying potential welfare gains. Finally, it is worth noting that while the presence of state-owned intermediaries fell drastically in the imports of all product categories - especially intermediate and capital goods - the number of state-owned

\footnotetext{
${ }^{8}$ More specifically, $64 \%$ of product lines are classified as intermediate goods, while final goods and capital goods represent only $21 \%$ and $15 \%$, respectively.
} 
producers decreased slightly when importing final goods, and even increased in purchasing foreign capital goods.

\subsection{Trade policy reforms}

During the 1990s, China started to implement relevant unilateral measures of trade liberalization in order to become a WTO member on December 11, 2001. Through the WTO accession protocol, China committed to applying MFN duties to all WTO members, to binding and further reducing all tariff rates, to removing several non-tariff barriers, and to extending trading rights to all firms. According to WTO's China Trade Policy Review (2006), China was seriously implementing all commitments, as scheduled by the protocol.

China's accession to WTO implied not only less uncertainty in exporting to China for worldwide firms, but also a decline in uncertainty in importing for Chinese firms from the rest of the World. It is worth noting that reduction in TPU uncertainty occurred at the same time for all products exported from China since, after it became a WTO member in 2001, China automatically benefited from the existing binding status of all WTO members' tariffs. Conversely, reduction in TPU uncertainty occurred in different years for products imported by China, as the tariff binding process had to be implemented gradually across products over time.

According to these WTO commitments, China would have to bind tariffs for all product lines: however, the year of ultimate implementation could be different across products for the tenyear period after becoming a WTO member. This means that the applied tariff was still allowed to be higher than the final bound tariff until the last year of scheduled implementation. Table 2 shows that the final tariff binding entered into force only for $57.3 \%$ of 6 -digit product lines upon China's accession to the WTO (i.e. since the year 2002). This share increased year after year until reaching $97.4 \%$ in 2006 , i.e. the remaining share of product lines would be subject to final binding in the following years, but no later than 2010 . 
When splitting the sample between $\mathrm{BEC}^{9}$ categories, we can see that, in 2002, intermediate goods exhibited the highest binding share $(66.0 \%)$, followed by capital goods $(54.3 \%)$, whereas final goods had the lowest binding share (32.6\%). However, all BEC categories then increased their binding share, reaching a similar status in 2006 (in the range of 96.7-99.2\%). Therefore, it seems that, upon China's accession to the WTO, protection through tariff uncertainty decreased drastically, but relatively more for domestic intermediate good producers than for domestic final good producers. This tariff binding process would therefore have generated larger initial benefits especially for domestic downstream firms (and foreign upstream firms), as it would have allowed greater access to foreign input varieties compared to foreign competing final varieties. In other words, productivity gains from input varieties within the downstream firms were likely to be larger than potential market shares losses arising from tougher foreign competition.

\section{Table 2 [Here]}

As regards applied tariffs, in 2000, intermediate goods exhibited the lowest applied tariff rate (13.5\%), followed by capital goods $(15.2 \%)$, whereas final goods had the highest tariff rate (25.2\%). However, tariff rates for all BEC categories decreased, almost halving their initial levels in 2006. It is worth noting that whereas tariffs on final goods decreased constantly over time until 2005 and then remained constant, the decline of tariffs on both intermediate goods and capital goods was more evident in 2002. Therefore, coherently with the previous discussion, it seems that, upon China's accession to the WTO, protection through applied tariffs decreased drastically, but relatively more for intermediate good production than final good production at home.

\footnotetext{
${ }^{9}$ BEC stands for Broad Economic Classification, which distinguishes goods according to their end-use in final goods, intermediate goods and capital goods.
} 


\section{Empirical strategy}

This section aims to explore product-level linkage between imports and trade policy uncertainty, by also taking into consideration changes in applied tariffs. Although Chinese import data are available at the country/product/firm level, the analysis is conducted at the product level, coherently with the previous literature on Chinese exports and foreign TPU (Handley and Limão, 2017; Feng, et al. 2017). ${ }^{10}$ Our baseline specification is given by the following reduced-form equation:

$$
\ln \left(V_{p t}\right)=\beta_{1} \text { Binding }_{p t-1}+\beta_{2} \text { Tariff }_{p t-1}+\beta_{3} X_{p t-1}+D_{p}+D_{t}+\varepsilon_{p t}
$$

where $V_{p t}$ stands for the import value for product $p$ in the year $t$, which can be decomposed in different components according the purpose of the analysis. Binding $g_{p t-1}$ is a dummy variable taking value one if the product $p$ is subject to the ultimate bound tariff in year $t-1$, and zero otherwise. It is our main variable of interest given that it captures the time when the tariff binding process is completed for a given product, so that China cannot increase applied tariff above a certain committed ceiling, implying a drastic reduction in trade policy uncertainty. Tariff $_{p-1}$ represents the simple average of the applied MFN tariff rate of product line $p$ in year $t-1$. Thus, we expect import value to increase following both tariff binding $\left(\beta_{1}>0\right)$ and applied tariff cuts $\left(\beta_{2}<0\right)$. Notice that to further reduce potential omitted variable bias, we also include additional control variables that reflect the presence of non-tariff import barriers for each

\footnotetext{
${ }^{10}$ The product-level foreign TPU measure (binding gap) used in previous studies on Chinese exports refers to a single trading country-partner (i.e. the US) in a given year prior to China's accession to WTO. Therefore, to explore within-product changes in Chinese exports due to US TPU reduction, the TPU measure has been interacted with a dummy taking value one if the destination is the US, as well as a dummy capturing the periods following China's entry to the WTO. Unlike these previous studies, our product-level domestic TPU measure (tariff binding status) additionally refers to all trading country-partners and varies across products and time. Indeed, when a tariff binding process is completed for a given product line in a given year, this trade reform automatically concerns all ordinary import transactions related to that product, regardless of the country of origin and firm characteristics. Notice that by exploiting only the variation of tariff binding status across products and time, rather than also across countries, should not be problematic given that almost the totality of Chinese import transactions at the firm/product/destination level occurred with WTO members during our sample period (i.e. $97 \%$ of observations). Indeed, when exploring also the country dimension in the subsequent analysis, our baseline results are confirmed.
} 
product $p$ in a given year $t\left(X_{p t-1}\right),{ }^{11}$ as well as product $\left(D_{p}\right)$ and year fixed effects $\left(D_{t}\right)$ to control for time-invariant product characteristics and common macroeconomic shocks across products. $\varepsilon_{p t}$ denotes the classical error term. Consequently, the estimated coefficient $\beta_{1} \beta_{1}$ in equation (1) can be considered an "average treatment effect among the treated" (ATT), since it is based on those products whose tariff binding status changed. All standard errors are corrected for clustering at the product level. Notice that our explanatory variables are lagged by one year with regard to the dependent variable, since import reactions to trade policy changes may not be immediate.

Following the previous discussions on how foreign TPU affects export value and the related margins, we expect that a reduction in Chinese TPU would allow China to increase its imports, through an increase in both the number of imported varieties and average imports per variety, due to the presence of sunk costs faced by foreign exporters (Handley, 2014; Handley and Limão, 2017). It is worth noting that in our context, a foreign variety refers to a 6-digit product/origin-country pair, as Handley (2014)'s approach. Consequently, when distinguishing the product-level import value $V_{p t}$ in the number of imported varieties and the average imports per variety, we are essentially disentangling the number of origin-countries $N_{p t}^{c}$ (countryextensive margin) and the average imports per origin-country $\bar{v}_{p t}^{c}$ (country-intensive margin), given that $V_{p t}=N_{p t}^{c} \bar{v}_{p t}^{c}$. Therefore, after exploring the tariff binding effect on import value within the product, we investigate whether this concerns country-extensive margin and/or country-intensive margin, by focusing in particular on the former margin. ${ }^{12}$

\footnotetext{
${ }^{11}$ NTB variables are: quota $_{p t-l}$ is a dummy variable taking value one if the product $p$ includes at least one 8-digitHS product subject to the import quota in the year $t-1$; tendering $p_{p t-1}$ is a dummy assuming value one if the product $p$ includes at least one 8-digit-HS product subject to import tendering in the year $t-1$; and license $p t-1$ is a dummy variable taking value one if the product category $p$ includes at least one 8-digit-HS product subject to the import license only in the year $t-1$. All NTB variables are based on information from the WTO accession protocol of China.

${ }^{12}$ A similar approach has been followed by previous studies that examined import adjustments to tariff liberalization (Goldberg, et al. 2010).
} 
Previous literature documented well that access to foreign intermediate inputs enhances firm productivity, through variety, quality and learning channels (Schor, 2004; Amiti and Konings, 2007, Goldberg, et al. 2010). More recent works have highlighted that only a small number of firms are able to import intermediate inputs because of the large sunk fixed costs of importing (Kasahara and Rodrigue, 2008; Kasahara and Lapham, 2013). Similar discussions are valid not only for producers involved in importing intermediate goods, but also for other kinds of firms (trade intermediaries) and goods (capital and final goods). Indeed, manufacturing firms may use both capital goods and final goods from abroad as inputs in their production process, and trade intermediaries can also face some sunk fixed costs of importing intermediate goods, final goods, and capital goods on behalf of both producers and final consumers. Thus, we also investigate whether tariff binding affects product-level import value $V_{p t}$, through a change in the number of importing firms $N_{p t}^{f}$ (firm-extensive margin) and/or the average imports per firm $\bar{v}_{p t}^{f}$ (firm-intensive margin), given that import value can be written alternatively as $V_{p t}=$ $N_{p t}^{f} \bar{v}_{p t}^{f}$, by focusing especially on the firm-extensive margin. ${ }^{13}$

Before analyzing the results, it is worth noting that trade policy reforms may be endogenous and that, consequently, problems of reverse-causality may occur when exploring the impact of trade policies on imports (Trefler, 1993). For instance, when import penetration is relatively high, domestic interest groups may lobby for more protection in terms of higher tariffs and/or postponing tariff binding. These concerns are not so relevant in our case, since all explanatory variables have been lagged by one period in our specification, and several works have documented that trade policy reforms in China, especially during the WTO accession period, were unlikely to be endogenous, as China's willingness to become a market economy was going

\footnotetext{
${ }^{13}$ A similar approach has been adopted by previous studies that analyzed export adjustments to foreign TPU reduction and tariff liberalization (Handley and Limão, 2015).
} 
beyond the interests of specific groups (Branstetter and Lardy 2008). For example, Brandt, et al. (2017) document an import tariff convergence to a similar level in all sectors over the period 1995-2007. Bas and Strauss-Kahn (2015) find an insignificant linkage between changes in tariffs in the period 2000-2006 and the initial industry characteristics. Similar results are found for both tariff and non-tariff barriers when considering the initial product characteristics (Imbruno, 2016). Therefore, all these empirical studies suggest that changes in tariff or nontariff barriers were highly exogenous in China during our sample period, i.e. unlikely to be influenced by sectors' performance or lobbying activities. Indeed, WTO's China Trade Policy Review (2006) documents that China was able to implement all its trade policy reforms, as scheduled by the WTO accession Protocol, including tariff binding.

Nevertheless, we also verify whether there is any correlation between a change in tariff binding (applied tariff) during the period of 2000-2006 and the initial product characteristics. Following Imbruno (2016), we include trade protection increasing variables - the import unit value, the share of the OECD economies in total source countries, the share of foreign-owned importers, and the share of trade intermediaries in total importing firms - as well as trade protection declining variables - China-specific import elasticity of substitution, computed by Broda, et al. (2006), and whether products were subjected to state trading and/or trading rights restrictions. ${ }^{14}$ Additionally, we also consider whether the product is final good, intermediate good or capital good, ${ }^{15}$ since Table 2 highlights the possibility that China favored foreign access to intermediate inputs and capital goods compared to final goods. ${ }^{16}$

\footnotetext{
${ }^{14}$ Domestic products would need less protection when foreign imported goods are relatively more expensive, and therefore less competitive. Export partners from OECD economies, as well as foreign-owned firms and trade intermediaries located in China may lobby to remove trade protection for products that they are primarily involved with. Products with a high elasticity of substitution, and product groups including varieties that were not freely traded, are more likely to be subject to trade protection measures.

15 The omitted group category is "other goods", i.e. those products that are not classified as final, intermediate or capital goods.

16 The binding share (applied tariff) was (on average) relatively higher (lower) for intermediate and capital goods than final goods, upon China's accession to the WTO.
} 
Table A.1 reports the results. Columns 1 and 2 show that changes in tariff binding during the period 2000-2006 do not have any statistically significant correlation with all explanatory variables, apart from the foreign share of importers. A reduction in TPU seems to be associated with a greater initial presence of foreign-owned importers, but is only weakly significant (i.e. at the statistical significance rate of $9 \%$ ). Tariff changes appear to be uncorrelated with the majority of initial product characteristics, except for time-invariant dummies capturing state trading, final good and capital good status. It seems that products subject to state trading, as well as those belonging to final good and capital good categories are associated with more intense tariff liberalization. It is, however, worth noting that all these time-invariant product characteristics are controlled for when the product fixed effects are included in equation (1). Since almost all products completed the binding process in 2006, this may explain the weak correlation with the explanatory variables. Therefore, in columns 3 and 4, we replicate the same regression by considering the change in tariff binding (applied tariff) between 2000 and 2002, when only about half of product lines had immediately completed the binding process. The results remain unchanged for applied tariffs, whereas tariff binding now appears to be delayed for products that are subject only to state trading. Again, this should not be problematic when controlling for product fixed effects in our baseline specification. Thus, strong exogeneity of both the tariff binding process and tariff liberalization policies in China is confirmed during our sample period.

\section{Results}

This section shows the results related to specification (1), by analyzing alternatively the country-related and firm-related margins of imports, in Section 4.1, and 4.2, respectively. We first explore how home TPU influences the number of country-varieties available within each product line and/or the average imports per country-variety. Then, we also investigate whether 
domestic TPU affects the number of importing firms within each product line and/or the average imports per firm. Finally, Section 4.3 includes additional investigations on firm-related extensive margin of imports to further explore how a Chinese firm's import decision adjusts to Chinese tariff binding.

\subsection{Country-analysis of product-level imports and trade policy}

\section{uncertainty}

Table 3 reports the results concerning the country-related analysis of the products. The first three columns show that tariff binding has a positive effect on product-level import value (by about $6.6 \%$ ), through an increase in both country-intensive and country-extensive margins (by about $5.3 \%$ and $1.4 \%$, respectively). Thus, domestic TPU reduction allows the Chinese economy to access additional foreign varieties, as well as to purchase more of each foreign variety. The results regarding the country-intensive margin are coherent with and complimentary to Handley and Limão's findings (2017), which document that product-level Chinese export value to the US increased drastically following a reduction in US trade policy uncertainty. It is worth noting that, as in their study, we cannot be sure whether domestic TPU reduction really implies the entry of new firm-varieties from a foreign country, since we cannot disentangle the number of firms exporting to China and their average export sales. However, unlike Handley and Limão (2017), who focus on the US's bilateral imports from China, we consider China's multilateral imports from all countries and, therefore, we are able to show in addition that a reduction in home TPU entails an increase in the number of source countries at the product level, which undoubtedly reflects the entry of new imported firm-varieties to the domestic market. Our results therefore also corroborate other studies' findings, which focus more on the firm-extensive margin of exports, documenting that a foreign TPU can delay a firm's decision to export (Handley, 2014; Handley and Limão, 2015). The applied tariff 
liberalization effects on import value and its related margins are also positive and statistically significant, coherently with our expectations.

\section{Table 3 [Here]}

In the next columns (from 4 to 7), we focus on the extensive margin by distinguishing between WTO and non-WTO members on the one hand, and OECD and non-OECD countries on the other. While we expect the TPU effect to concern relatively more suppliers from WTO countries, it will be interesting to see whether there is any trade diversion or creation with regard to non-WTO members. We would also expect tariff binding to have a greater effect on suppliers from developed economies, since China was at that time more likely to be involved in a tariff war with advanced economies (such as the US and EU) rather than developing countries. ${ }^{17}$ Our results show that while a reduction in applied tariff leads to an increase in the number of country-varieties from all groups of countries, regardless of their WTO or OECD status, tariff binding allows access to a greater number of varieties only from WTO members and developed countries, as expected. To the extent that products from developed economies are associated with higher quality (Bas and Strauss Kahn, 2015), we can reach the conclusion that a reduction in home trade policy uncertainty leads China to access more varieties of high quality. These results are therefore coherent with and complementary to the findings of Feng, et al. (2017), which document that TPU reduction arising from China's accession to the WTO implied an increase in the quality of Chinese exported varieties. Combining our results with theirs, it is possible to surmise that TPU reduction allowed Chinese firms to upgrade the quality of their exported varieties, by improving their access to high-quality goods from abroad, either

\footnotetext{
${ }^{17}$ Indeed, developed countries are on average more likely to be involved in WTO Dispute Settlement (DS) than developing countries, as either complainant or respondent (Johannesson and Mavroidis, 2016). By looking at the China's case, since its entry to the WTO in 2001, China has been involved in DS, as either complainant or respondent, always with a developed country (mostly the US and EU), except for one case with Brazil.
} 
imported final varieties (learning/competition channel) or intermediate varieties (input channel). ${ }^{18}$

In Table 4, we distinguish the tariff binding effect among final goods, intermediate goods and capital goods, following the BEC classification. First, the effects documented above are strongly confirmed for intermediate goods - with an even larger order of magnitude - and are slightly less evident for final goods - since when we split the extensive margin between WTO and non-WTO or OECD and non-OECD, the coefficients of tariff binding become statistically non-significant. Therefore, while Chinese final consumers seem to enjoy a greater variety of foreign final goods owing to tariff binding, Chinese producers seem to benefit from both the greater variety and better quality of foreign intermediate inputs. These results would suggest that potential quality upgrading of Chinese exported varieties is more likely to occur through improved access to high-quality intermediate varieties, rather than through learning/competition effects from high-quality competing final varieties.

\section{Table 4 [Here]}

Interestingly, we find opposite results for capital goods: tariff binding implies a decline in product-level imports, in terms of both intensive and extensive margins, and the reduction in variety of foreign capital goods concerns all groups of countries, regardless of WTO or OECD status. This dissimilarity compared to other BEC product categories may be linked to the difference in the nature of goods: while consumption in foreign final and intermediate goods requires importing periodically and systematically every year, the consumption of capital goods occurs with less import frequency, since capital goods are long-run investments. We come back to this issue with further details in the next sections. Therefore, it would seem that China's trade

\footnotetext{
${ }^{18}$ Previous literature has already highlighted that output tariff cuts are associated with product quality upgrading, since firms may be pushed to invest more in innovation following tougher import competition or learn more sophisticated technologies embodied in the foreign goods (Amiti and Khandelwal, 2013). Bas and Strauss-Kahn (2015) show that a reduction in input tariffs allowed Chinese producers to use high-quality inputs from abroad, implying quality improvements of their exported products.
} 
policy uncertainty tended to delay world-wide firms' decisions to export final and intermediate goods to China, and to hasten their decisions to export capital goods.

\subsection{Firm-analysis of product-level imports and trade policy uncertainty}

Table 5 displays the results concerning firm-related analysis within the products. Columns 13 show that tariff binding positively affects product-level import value (by about 6.6\%), through an increase in both firm-intensive and firm-extensive margins (by about $3.7 \%$ and $3.0 \%$, respectively). Thus, Chinese TPU reduction allows more Chinese firms to enter import markets, as well as more foreign purchases per (incumbent) importing firm. Similar effects are found with a reduction in applied tariffs, coherently with our expectations.

\section{Table 5 [Here]}

In columns 4 and 5, where we distinguish the extensive margin by considering the macro-sector of firms, i.e. between the number of importing producers and the number of importing intermediaries, we can see that both TPU reductions and applied tariff cuts generate positive effects for both firm groups. However, it is worth noting that while tariff liberalization dramatically benefits the entry of trade intermediaries rather than producers into the import market, the positive impact of tariff binding is slightly larger for producers (2.8\% versus $2.2 \%$ ), suggesting that manufacturing firms have more incentive to start importing directly after TPU reduction. This is not surprising since intermediaries' import transactions are associated with larger sunk costs compared to producers' import transactions. For instance, Ahn, et al. (2011) find that, in China, intermediaries tend to trade with markets that are more difficult to penetrate - which are associated with larger sunk costs - compared to producers. Considering that large sunk costs make firms postpone their import decisions when TPU is high, subsequent to TPU reduction, import entry is expected to be higher for producers than for intermediaries. However, the difference in the binding effect between producers and intermediaries is not so large. This 
may be due to the role of irreversibility arising from complementarity with the production technology, which is of relatively more concern to producers. Indeed, high irreversibility makes firms postpone their import decisions when TPU is high, so that, following TPU reduction arising from tariff binding, import entry may increase relatively less for producers compared to intermediaries. Notice however that irreversibility from complementarity with production technology may also regard trade agents' import transactions, as long as the intermediaries operate on behalf of certain producers (indirect importing manufacturers).

When exploring ownership status in Table 6, we can see that the positive binding effect is confirmed for both foreign-owned (with an even larger order of magnitude) and state-owned producers, whereas the number of domestic-private importing producers appears to shrink following TPU reduction. In compensation, domestic-private importing producers would benefit relatively more from applied tariff reductions than other producers.

\section{Table 6 [Here]}

The reason why foreign affiliates import more than domestic private firms when TPU is reduced may be that the former have lower sunk costs, thanks to the presence of their multinational network around the globe. Moreover, foreign-owned firms are more likely than domestic private firms to be involved with processing imports already, even before starting to import under ordinary trade regime, and therefore they will already have paid some sunk costs of importing in the past. Consequently, it is relatively easy for foreign affiliates to start ordinary imports (those that already had some import experience under the processing trade regime) compared to domestic private firms (which did not import at all) following tariff binding. This might be a signal that a reduction in TPU causes a greater number of foreign-owned producers located in China to serve the local market (importing more under the ordinary regime), rather than simply assembling the final output for the global market (importing more under the processing regime). 
As regards trade intermediaries, while tariff liberalization leads more non-foreign-owned intermediaries to enter import markets (especially the private ones), tariff binding allows more non-state-owned intermediaries to start importing (especially foreign ones). Thus, it seems that TPU reduction attracts greater FDI flows in the trade services sector. This may also help to explain why the number of domestic-private importing producers has shrunk following TPU reduction. Indeed, the sunk costs implied in starting to import a given product directly may be relatively higher for domestic-private producers compared to foreign producers, given that the latter may benefit from their multinational network and/or processing import experience. At the same time, the increasing presence of private-owned wholesalers in importing may be an incentive for domestic-private producers to switch from the direct to the indirect mode of importing, given that trade agents, especially foreign-owned ones, have greater knowledge and expertise in searching and matching suppliers and customers within an international context.

When examining the end-use nature of goods (Table 7), we notice that subsequent to tariff binding, the product-level import value increases through both firm-intensive and firmextensive margins only for intermediate goods. Indeed, final good imports increase only through the intensive margin, whereas capital good imports decrease through both margins. Therefore, it seems that TPU reduction allows a larger number of Chinese firms to enjoy potential gains from trade in intermediate inputs, reducing however potential gains from importing capital goods across firms. These results confirm the hypothesis that TPU tends to postpone a firm's decision to purchase foreign intermediate inputs and hasten a firm's decision to invest in foreign capital goods.

These opposite effects may be due to the different nature of goods. If a firm starts importing intermediate goods in the current period, it needs to purchase these goods periodically every year for some subsequent periods, given the high irreversibility of the import decision (Ramanarayanan 2017). This means that a firm cannot easily change its import status, which is 
therefore more persistent over time, relatively speaking. As a result, the firm has to face the risk of a drastic increase in tariffs every year after starting to import intermediate goods, which would entail a decrease in profits. Thus, if the firm is afraid of an imminent increase in (unbounded) tariffs on intermediate goods, it prefers to postpone its decision to import. Therefore, following TPU reduction arising from tariff binding, the probability of importing intermediate goods may increase.

Conversely, if a firm starts importing capital goods in the current year, it does not need to purchase these goods periodically every year over subsequent periods, given that they are longterm investments. This means that the import status of a firm is relatively less persistent over time. As a result, after starting to import capital goods, a firm will not be subject every year to a risky reduction in profits due to potential tariff increases, since it will deduct "certain" shares of amortization when calculating the/its profit. Thus, if the firm fears an imminent increase in (unbounded) tariffs on capital goods, it has no incentive to postpone the decision to import. Conversely, the firm will tend to purchase foreign capital goods immediately, even if it needs them only in subsequent periods. Through TPU reduction subsequent to tariff binding, the probability of importing capital goods may therefore decrease.

By accounting for the number of years that a producer is involved in importing each BEC group of products during the seven years of our sample period (2000-2006), we find that a median firm imports capital goods for only one year, and intermediate goods for three years. This confirms that the purchase of capital goods is relatively more sporadic than the purchase of intermediate goods.

As a result, following Chinese tariff binding, world-wide firms' export opportunities in China increased for producers of intermediate goods and decreased for producers of capital goods. Indeed, in the previous section, we found that following Chinese tariff binding, the number of 
imported varieties (which corresponds to the number of source countries in our case) in China increased for intermediate goods and decreased for capital goods.

\section{Table 7 - [Here]}

Furthermore, intermediate goods seem to be imported by a larger number of producers (i.e. SOEs and FORs) and intermediaries (i.e. SOEs and PRIVs), whereas final goods are imported by more trade agents (i.e. FORs) and fewer domestic producers (i.e. SOEs and PRIVs). These results further confirm that following TPU reductions: $a$ ) more manufacturing firms are able to import foreign intermediate inputs directly or indirectly, ${ }^{19}$ and therefore enjoy potential productivity gains; $b$ ) foreign multinationals in China tend to be more market-seeking than simply resource-seeking (considering the drastic increase in both inward FDI in manufacturing firms associated with importing intermediate inputs under ordinary regime, and inward FDI in distribution firms associated with importing final goods). Finally, the considerations made with regard to imports of capital goods actually concern only domestic firms (i.e. domestic-private owned producers and state-owned trade agents), given that subsequent to TPU reduction, a larger number of foreign firms (both producers and trade agents) buy foreign capital goods. It should be noted that the increasing role of foreign-owned trade intermediaries in importing capital goods contributes to explain why domestic private-owned producers are less involved in directly importing capital goods following a reduction in TPU. In other words, tariff binding may result in domestic producers benefitting from a more profitable acquisition of foreign capital goods through foreign-owned trade agents than purchasing foreign capital goods directly from abroad.

\footnotetext{
${ }^{19}$ Notice that the binding effect on imports of intermediate goods turns out to be positive, although not statistically significant, for domestic private-owned producers. This insignificance could partially be due to the increasing role of domestic private-owned wholesalers in importing intermediate goods after tariff binding. Therefore, it seems that following a fall in TPU, domestic-private producers possibly find purchasing foreign intermediate goods through wholesalers more profitable than directly importing those goods.
} 


\subsection{Further investigations}

In this section, we further explore how Chinese tariff binding affected Chinese firms' participation in import markets, by implementing some robustness checks or deeper investigations that complement the previous analysis. All related tables are reported in the Appendix.

Tariff Binding Gap. Our analysis of Chinese firms' import adjustments to the reduction of domestic TPU takes advantage of the time-varying tariff binding status of product lines, rather than of the binding overhang, as exploited by former studies on Chinese exports and foreign TPU (Handley and Limão, 2017; and Feng, et al. 2017). ${ }^{20}$ The binding overhang cannot be exploited in our context because there was almost no difference between the bound rate (Bound) and the applied tariff rate (Tariff) imposed by China after the binding process was completed in China during the WTO accession period. Indeed, by measuring the Chinese binding gap as follows ${ }^{21}$

$$
\text { Binding Gap }=\frac{1+\text { Tariff }}{1+\text { Bound }}
$$

the mean value of binding gap (0.57272) is almost equivalent to the mean value of binding dummy (0.57311). The correlation between these two variables equals 1 . Moreover, when the binding process has been completed (i.e. when Binding =1), Binding Gap tends to be very close to $1 .^{22}$ Therefore, changes in Chinese TPU over time mainly occurred through the binding status of products, rather than changes in binding gap. When replacing the variable Binding

\footnotetext{
${ }^{20}$ Chinese exports to US were found to increase relatively more with respect to other destinations after China's accession to the WTO, especially in sectors initially associated with a larger gap between the US worst-case tariff and the US applied tariff, i.e. larger tariff uncertainty.

${ }^{21}$ The binding gap, as computed here, can go from 0 (highest TPU, when the tariff is not bound and therefore Bound tends to infinite) to 1 (lowest TPU, when the tariff is bound and Tariff $=$ Bound).

${ }^{22}$ When Binding $=1$, the mean value of Binding Gap is 0.99932, its lowest value is 0.86819 , and more than 90 percent of observations have the binding gap that equals 1.
} 
with Binding Gap in the baseline specification (equation 1), the results, displayed in Table A.2, remain almost identical.

Foreign TPU effect. In the current study, we focus on the direct impact of domestic TPU on Chinese imports, coherently with previous studies on tariff liberalization (Bas and StraussKahn, 2015; Imbruno, 2016), rather than on the direct effect of foreign TPU on Chinese exports, which is already documented by the literature (Handley and Limão, 2017; and Feng, et al. 2017). We also neglect the indirect effect of foreign TPU on Chinese imports, i.e. how lower foreign TPU makes Chinese firms export more and, consequently, demand more intermediate inputs.

Unfortunately, the latter effect cannot be explored within a similar econometric setting, given that while Chinese tariff binding is time-varying across products, foreign tariff binding (including US tariff binding) automatically occurred for all products in China after its accession to the WTO (i.e. from 2002 onwards). Consequently, foreign tariff binding is captured by year fixed effects in our econometric specification.

Nevertheless, to ensure that the effect of domestic TPU on Chinese imports is not confounded with the impact of foreign TPU on Chinese exports, we consider, as a robustness check, only firms involved exclusively in import activities, excluding all importers who are also engaged in exporting. The results, shown in Table A.3, remain analogous since, subsequent to tariff binding, the import value increased through both firm-intensive and firm-extensive margins. Nevertheless, the effects of TPU on the number of trade intermediaries are now less evident, probably because the majority of them are simultaneously involved in import and export activities, and have therefore been dropped in this sensitivity analysis. 
The role of import frequency. Interestingly, we found in the previous sections that TPU reduction implied an increase in the number of firms importing intermediate goods and a decrease in the number of firms importing capital goods. We argued that this might be due to the different nature of goods, since intermediate goods need to be purchased more frequently than capital goods. Now, we attempt to explore more deeply whether import frequency plays any role in explaining the different binding effects across BEC groups of products. First, we compute a product-specific import frequency, by computing the number of years that a producer $^{23}$ is involved in importing each 6-digit product during the sample period of seven years, and then by calculating its mean across firms within the product. Second, we interact this product-specific import frequency with the binding dummy for each BEC category in the regression analysis. The coefficient of this interaction term is expected to be positive, since if a product is on average more frequently purchased by a firm, the positive binding effect on the number of importing firms should be larger.

Table A.4 shows the results. First, by focusing our attention on intermediate and capital goods, we always find a positive interaction term coefficient (except for foreign-owned firms importing capital goods), which suggests that firm propensity to start importing is more sensitive to tariff binding when the product is frequently purchased by the firm, in line with our expectations. As regards intermediate goods, when controlling for import frequency, the positive and significant binding effect originally found for the number of importing state-owned and foreign-owned producers in Table 7 becomes statistically insignificant. By contrast, the initially insignificant effect found for domestic-private firms becomes negative and statistically significant, but turns to positive when the import frequency is relatively high. With reference to capital goods, when controlling for import frequency, the negative binding effect on the

\footnotetext{
${ }^{23}$ We exclude here the cases of trade intermediaries since, as they import on behalf of many producers, they are likely to be involved in importing all BEC groups of goods every year.
} 
number of importing producers is strongly confirmed for both state-owned and domesticprivate firms and switches to positive if the import frequency is relatively high. At the same time, the positive binding effect for foreign-owned firms is found to be robust to the inclusion of import frequency. Overall, these results suggest that import frequency plays an important role in explaining firm-related extensive margin response to tariff binding for both capital and intermediate goods.

Import reaction to tariffs when tariffs are bound. The literature on exports and TPU mainly focuses on the 'delay hypothesis', i.e. whether TPU defers a firm's entry in the export market (Handley and Limão, 2015; Handley and Limão, 2017; Feng, et al. 2017). Likewise, the current study mostly explores whether TPU postpones a firm's entry in the import market. Handley (2014) also highlights that TPU makes a firm's decision to export less sensitive to applied tariff reductions ('caution hypothesis'). We now investigate whether, when tariffs are bound, product-level imports also adjust differently to applied tariff reductions, by distinguishing the extensive and intensive margins in terms of firms. We therefore include an additional term of interaction between the variables Binding and Tariff in our baseline specification, whose coefficient is expected to be negative. Table A.5 reports the results. First, we notice that the binding effect is more evident for products that are not subject to applied tariff changes. Second, the applied tariff effect on import value is found to be larger for products subject to tariff binding. Since this mainly regards the firm-extensive margin, this empirical exercise also confirms the caution hypothesis for import behavior. Indeed, the positive tariff liberalization effect on the number of importing firms doubles in size when the tariff is also subject to the binding process.

Processing imports. Processing import transactions have been excluded in our analysis since they are not subject to applied tariffs and, consequently, are not directly affected by a change 
in our TPU measure, i.e. tariff binding. Indeed, a Chinese firm that wants to start importing under ordinary trade regime is concerned about potential increases in tariffs in the following periods, given that the firm's marginal costs (productivity) may drastically increase (decline) in the future. Conversely, when a Chinese firm takes into consideration the possibility of starting to import under the processing trade regime, it is not so worried about potential higher tariffs in the subsequent periods, since its imports are duty-free.

However, indirect effects of tariff reforms may also occur on processing import transactions. Brandt and Morrow (2017) documented that the drastic shift from processing to ordinary trade in China during the period 2000-2006 was caused by input tariffs cuts. By developing a theoretical model based on the trade-off resulting from the firm's decision to trade under ordinary regime (associated with tariffs on imported inputs and output sales to both domestic and foreign markets) or processing trade regime (associated with duty-free imported inputs and output sales only to foreign markets), they show that lower input tariffs reduce firms' incentives to organize through processing trade. Next, the authors show empirically that the ordinary shares of both imports and exports enhance subsequent to input tariff reduction. In particular, they also demonstrate that input tariff declines entail a drastic increase in ordinary export value and a (statistically insignificant) decrease in processing export value at the product (-province) level. Likewise, tariff binding may lead firms to start importing under ordinary trade regime, indirectly implying a negative or no effect on importing under the processing trade regime.

Therefore, in Table A.6, we explore the reaction of processing imports to tariff reforms. First, coherently with Brandt and Morrow (2017), we find similar patterns for import value, i.e. while the ordinary import value increases following tariff cuts, the processing import value declines. We also find that this effect is mainly due to the intensive margin, given that the number of firms increases. This effect on extensive margin regards both foreign-owned and domestic- 
private firms, since the number of state-owned firms declines. Second, and more importantly in our study, we find no significant tariff binding effect on processing imports, and its firmrelated margins, except for a reduction in the number of domestic-private firms. Therefore, the firm's decision to be involved in processing trade is mainly not affected (or sometimes positively influenced) by TPU, in line with our expectations.

Country/product level analysis. The analysis so far has been conducted at the product level mainly because our main explanatory variable (Binding dummy) varies at the product/year level. Therefore, we have first examined how tariff binding affects total import value at the product level, by disentangling the extensive and intensive margin in terms of country-origin (i.e. the number of countries and average imports per country). This analysis basically corroborates the previous findings on (foreign) export adjustments to (Chinese) TPU reduction (Handley, 2014; Handley and Limão, 2015; Handley and Limão, 2017; Feng, et al. 2017). Next, we have explored how both extensive and intensive margins of product-level import value in terms of firms (i.e. number of firms and average imports per firm) react to tariff binding, to observe whether a reduction in (Chinese) TPU also affects the number of (Chinese) firms involved in import activities, thus providing interesting new insights. This product-level approach is in line with several studies in the literature that analyze the impact of tariff liberalization on imports (e.g. Goldberg, et al. 2010), as well as those regarding the TPU effect on exports (Handley and Limao, 2015).

We now replicate the analysis at the country/product level, by splitting the import value between the number of importing firms and average importers per firm within each product/country pair. In this way, when investigating adjustments of firm-related margins to tariff binding, we are able to control for country heterogeneity in addition to product heterogeneity, by replacing product fixed effects with country/product fixed effects. Notice that our main explanatory variable of interest (Binding) is now varying at the product/country/year 
level, and not simply at the product/year level, since it turns out to be always zero when the source country is a non-WTO member. Table A.7 shows that the main results on the extensive margins are strongly confirmed, i.e. following tariff binding, both the number of importing producers (SOEs and FORs) and the number of importing intermediaries (FORs and DPRIVs) increase. $^{24}$

Firm/product(/country) level analysis. When exploring how TPU may influence the extensive margin of importing firms, we follow a similar approach as outlined in other studies on the effects of TPU on the extensive margin of exporting firms that have similar data dimensions, i.e. trade data at the firm/product(sector)/country level. All these studies implement a product (sector) analysis by relating the number of exporting firms to a TPU measure at the product (sector) level (Handley and Limão, 2015; Feng, et al. 2017).

An alternative way to explore how tariff binding may affect the extensive margin in terms of importing firms is an analysis at the firm/product(/country) level that links the import status of firm/product(/country) pair (triplet) with the product(/country)-level TPU measure. The intention being to investigate how tariff binding may influence the probability that a firm $f$ imports a given product $p$ (from a given country $c$ ) through a linear probability model (LPM), which would allow capturing firm heterogeneity (and country heterogeneity), in addition to product heterogeneity.

\footnotetext{
${ }^{24}$ Similar results are found when considering the binding status variation at the product/year level only. Results are available upon request.
} 
Notice that in order to estimate the LPM, we first have filled in the time gaps for each observed firm/product(/country) pair (triplet) ${ }^{25}$ and then focused our attention on importing producers, ${ }^{26}$ by building a dataset of about 16 millions ( 22 millions) observations. Then, the following specification has been estimated

$$
M_{f p(c) t}=\beta_{1} \text { Binding }_{p(c) t-1}+\beta_{2} \text { Tariff }_{p t-1}+\beta_{3} X_{p t-1}+D_{p(c)}+D_{f t}\left(+D_{c t}\right)+\varepsilon_{f p(c) t}
$$

where $M_{f p(c) t}$ is a dummy variable that takes the value one if a firm $f$ imports a given product $p$ (from a given country $c$ ), and zero otherwise. Our main explanatory variable remains Binding $_{p(c) t-1}$ which is a dummy variable that takes the value one if the product $p$ (from a given country $c$ ) is subject to the ultimate bound tariff in year $t-1$, and zero otherwise. ${ }^{27} \mathrm{We}$ also control for the applied tariff and other product-level controls (i.e. NTB variables) coherently with previous analysis. Finally, we consider product(/country) fixed effects $D_{p(c)}$ that help to control for all time-invariant characteristics at the product(/country) level - including the sunk fixed costs of importing that are common across firms - as well as the firm/year fixed effects (and the country/year fixed effects) that capture all time-varying characteristics at the firm level, such as firm productivity and firm ownership status ${ }^{28}$ (and all time-varying country characteristics).

\footnotetext{
${ }^{25}$ Notice that in order to estimate the LPM, we would need information on all firms that do not import at all, whereas we have data only on importing firms. Although the estimates might suffer of selection bias problems, we should at least extend our dataset to all possible combinations of observed firm/products/(country) pairs (triplets) over seven years. This strategy would lead to a very large dataset (of about 1,000 billion observations) which is difficult to manage. Alternatively, we have just filled in the time gaps for each observed firm/product(/country) pair (triplet), by worsening however the selection bias problem. Thus, the results of this specification need to be read with these caveats in mind.

${ }^{26}$ Trade intermediaries have been excluded because their import decisions may be affected not only by their characteristics, but also by the indirect importing producers' characteristics that we cannot control for.

${ }^{27}$ Notice that when considering the country dimension in addition to the product dimension, the binding status is varying not only at product/year level, but also at product/country/year level, given that it is always zero across products when the country-destination is not a WTO member during our sample period.

${ }^{28}$ Notice that firm-ownership heterogeneity of binding status (through interaction terms) cannot be explored as when the import dummy is zero, the firm-ownership status information is missing.
} 
Table A.8 displays the results where all standard errors have been corrected for clustering at the product level. The first four columns concern the firm/product level analysis, whereas the last four columns regard the firm/product/country level analysis. The two analysis show similar findings. Columns 1 (5) reports the results of equation 2, where we can observe that the binding effect is strongly confirmed, suggesting that the probability that a firm imports a given product (from a given country) increases following TPU reduction. The applied tariff effect remains negative, although it seems to be statistically not significant. However, when including the interaction term between binding status and applied tariff in Column 2 (6), we see that the negative effect of the applied tariff on the import decision is statistically significant when the tariff is bound, while the binding effect alone becomes even larger. Therefore, these results seem to suggest that import activities are associated with relevant sunk fixed costs, which can discourage a firm's decision to purchase foreign goods in presence of TPU.

Previous literature found that sunk costs of importing could be even larger than those of exporting (Muûls and Pisu, 2009). This may be due to the fact that before starting import activities, firms need to face not only sunk costs at product(/country) level that are similar to those of exporting (i.e. costs of searching trade partners), but also some further sunk investments in order to absorb foreign intermediate inputs in their stages of production. In order to investigate this, we check whether the current import status is positively correlated with past import status, despite the inclusion of product/(country) fixed effects that would capture all product(/country)-specific sunk costs. Indeed, previous studies highlighted that the presence of sunk costs of importing (exporting) generates hysteresis in import (export) market participation (Muûls and Pisu, 2009). Therefore, we include a lagged dependent variable amongst the explanatory variables in equation 2, whose coefficient is expected to be positive if importers face additional sunk costs to absorb foreign inputs, in addition to the market-specific sunk costs that are already captured by product(/country) fixed effects. In Column 3 (6) we find results, 
which are in line with this hypothesis: the current import status is positively correlated with the past import status. Since these results could still be due to some remaining complementarity between import and export sunk costs, we exclude this hypothesis by including also the past export status and its interaction with the past import status in column 4 (8). It is worth highlighting that the binding effect remains positive and statistically significant in all specifications.

\section{Conclusion}

Trade policy uncertainty (TPU) plays an important role in firms' decisions to trade. Recent works have already stressed that firms face sunk fixed costs of exporting and showed that, by reducing the fear that trade tariffs may suddenly increase without any limit, firms will have more incentive to start exporting. Unlike the existing literature, we focus on import rather than export behavior, considering that firms also need to pay the sunk fixed costs of importing foreign goods, so that TPU reduction may affect firms' decisions to be involved in different stages of global value chains.

Analyzing product-level Chinese import adjustments to tariff binding during the period 20002006, as scheduled by China's WTO accession protocol (which entered into force in December 2001), our baseline results show that the Chinese economy can access more foreign varieties, especially from developed countries, which are typically associated with high-quality. We have also found that tariff binding leads foreign products to be imported by a larger number of Chinese firms, involved in either manufacturing production or trade intermediation services, extending potential gains from imports amongst more producers and final consumers located in China. 
We have also documented heterogeneity across products associated with different end-use. Our findings suggest that tariff binding in China allows more manufacturing firms to access a greater variety of intermediate inputs, also associated with high-quality, which could partially explain the productivity gains and quality upgrading from trade liberalization documented by former studies. However, we find opposite results when considering capital goods, which suggests that TPU tends to delay a firm's decision to import intermediate inputs, and hasten a firm's decision to import capital goods.

Finally, our results highlight that tariff binding pushes more foreign-owned firms located in China to be market-seeking, rather than resource-seeking. In other words, a decline in Chinese TPU allows multinationals to relocate the downstream stages of global value chains in China, relatively more than the upstream stages.

These new stylized facts may represent a call for further research in the future on trade policy uncertainty and firms' import behavior, to further explain potential welfare gains from reducing trade barriers. For instance, it would be interesting to explore more deeply how Chinese TPU reduction has affected domestic firms' decision to upgrade quality and/or technology, or foreign firms adjust their exports to Chinese tariff binding. 


\section{References}

Ahn, J. B., Khandelwal, A. K., and Wei, S-J., 2011. "The role of intermediaries in facilitating trade," Journal of International Economics, 84 (1): 73-85.

Amiti, M., and A. K. Khandelwal (2013). "Import Competition and Quality Upgrading”. The Review of Economics and Statistics, 95(2): 476-490.

Amiti, M., and Konings, J. (2007). "Trade Liberalization, Intermediate Inputs, and Productivity: Evidence from Indonesia". American Economic Review, 97 (5): 1611- 1638.

Andersson, M., Johansson, S., and Lööf, H. (2007). "Productivity and International Trade firm-level evidence from a small open economy," Working Paper Series in Economics and Institutions of Innovation 99, Royal Institute of Technology, CESIS - Centre of Excellence for Science and Innovation Studies.

Bas, M. and Strauss-Kahn, V. (2014). "Does importing more inputs raise exports? Firm-level evidence from France," Review of World Economics, 150 (2): 241-275.

Bas, M., and Strauss-Kahn, V. (2015). "Input-trade liberalization, export prices and quality upgrading". Journal of International Economics, 95, 250-262.

Bøler, E. A., Moxnes, A., and Ulltveit-Moe, K. H. (2015). "R\&D, International Sourcing, and the Joint Impact on Firm Performance," American Economic Review, 105 (12): 37043739.

Brandt, L., Morrow, P. M. (2017). "Tariffs and the organization of trade in China," Journal of International Economics, 104(C): 85-103.

Brandt, L., Van Biesebroeck, J., Wang, L., and Zhang, Y. (2017). "WTO Accession and Performance of Chinese Manufacturing Firms". American Economic Review, 107(9): 2784-2820.

Branstetter, L., and Lardy, N. R. (2008). “China's embrace of globalization.” In L. Brandt, \& T. G. Rawski (Eds.), China's economic transition: Origins, mechanisms, and consequences. New York: Cambridge University Press 829-826.

Feng, L., Li, Z., and Swenson, D. L. (2017). "Trade Policy Uncertainty and Exports: Evidence from China's WTO Accession". Journal of International Economics, 106, Pages 20-36

Goldberg, P. K., Khandelwal, A. K., Pavcnik, N., and Topalova, P. (2010). "Imported Intermediate Inputs and Domestic Product Growth: Evidence from India". The Quarterly Journal of Economics, 125 (4): 1727-1767.

Handley, K. (2014). "Exporting under trade policy uncertainty: theory and evidence". Journal of International Economics, 94(1), 50-66.

Handley, K., and Limão, N. (2015). "Trade and investment under policy uncertainty: theory and firm evidence". American Economic Journal: Economic Policy, 7 (4), 189-222.

Handley, K., and Limão, N. (2017). "Policy Uncertainty, Trade, and Welfare: Theory and Evidence for China and the United States". American Economic Review, 107(9): 27312783.

Imbruno, M. (2016). "China and WTO liberalization: Imports, tariffs and non-tariff barriers". China Economic Review, 38(C): 222-237.

Johannesson, L., and Mavroidis, P. C. (2016). "The WTO Dispute Settlement System 19952016: A Data Set and its Descriptive Statistics”. EUI Working Paper RSCAS 2016/72.

Kasahara, H. (2004). "Technology adoption under relative factor price uncertainty: the puttyclay investment model". Working paper. University of British Columbia.

Kasahara, H., and B. Lapham (2013). "Productivity and the Decision to Import and Export: Theory and Evidence". Journal of International Economics, 89 (2): 297-316.

Kasahara, H., and J. Rodrigue (2008). "Does the use of imported intermediates increase productivity? Plant-level evidence". Journal of Development Economics, 87 (1): 106118. 
Lööf, H., and Andersson, M. (2010). "Imports, Productivity and Origin Markets: The Role of Knowledge-intensive Economies". The World Economy, 33 (3):458-481.

Manova, K., and Yu, Z. (2016). "How firms export: Processing vs. ordinary trade with financial frictions". Journal of International Economics, 100(C): 120-137.

Mau, K. (2017). "US policy spillover(?) - China's accession to the WTO and rising exports to the EU". European Economic Review, 98(C): 169-188.

Miaojie Yu (2015). "Processing Trade, Tariff Reductions and Firm Productivity: Evidence from Chinese Firms". Economic Journal, 125 (585): 943-988.

Muûls, M., and Pisu M. (2009). "Imports and Exports at the Level of the Firm: Evidence from Belgium," The World Economy, 32 (5): 692-734.

Pierce, J.R., and P. K. Schott (2016). "The Surprisingly Swift Decline of US Manufacturing Employment”. American Economic Review, 106 (7), pages 1632-1662.

Ramanarayanan, A. (2017). "Imported inputs, irreversibility, and international trade dynamics". Journal of International Economics, 104(C):1-18.

Roberts, M.J., and Tybout, J.R. (1997). "The decision to export in Colombia: an empirical model of entry with sunk costs". American Economic Review. 87 (4), 545-564.

Roberts, M.J., and Tybout, J.R. (1997). "The decision to export in Colombia: an empirical model of entry with sunk costs". American Economic Review. 87 (4), 545-564.

Schor, A. (2004). "Heterogeneous productivity response to tariff reduction. Evidence from Brazilian manufacturing firms". Journal of Development Economics, 75 (2): 373-396.

Trefler, D. (1993). "Trade liberalization and the theory of endogenous protection: An econometric study of US import policy." Journal of Political Economy, 101 (1), 138160.

WTO (2006). China Trade Policy Review, WT/TPR/S/161.

Zhang, Hongsong (2017). "Static and dynamic gains from costly importing of intermediate inputs: Evidence from Colombia”. European Economic Review, 91(C): 118-145. 


\section{Tables}

Table 1 - Product level imports in China over the 2000-2006 period

\begin{tabular}{|c|c|c|c|c|c|c|c|c|c|c|c|c|c|c|c|c|}
\hline \multirow[b]{3}{*}{ Variable } & \multicolumn{4}{|c|}{ ALL GOODS (N=4090) } & \multicolumn{4}{|c|}{ FINAL GOODS (N=859) } & \multicolumn{4}{|c|}{ INTERMEDIATE GOODS ( $\mathrm{N}=2613$ ) } & \multicolumn{4}{|c|}{ CAPITAL GOODS (N=610) } \\
\hline & \multicolumn{2}{|c|}{2000} & \multicolumn{2}{|c|}{$\begin{array}{c}\text { Change } \\
2000-06\end{array}$} & \multicolumn{2}{|c|}{2000} & \multicolumn{2}{|c|}{$\begin{array}{c}\text { Change } \\
2000-06\end{array}$} & \multicolumn{2}{|c|}{2000} & \multicolumn{2}{|c|}{$\begin{array}{c}\text { Change } \\
2000-06\end{array}$} & \multicolumn{2}{|c|}{2000} & \multicolumn{2}{|c|}{$\begin{array}{c}\text { Change } \\
2000-06 \\
\end{array}$} \\
\hline & Mean & $\begin{array}{l}\text { Std. } \\
\text { Dev. }\end{array}$ & Mean & $\begin{array}{l}\text { Std. } \\
\text { Dev. }\end{array}$ & Mean & $\begin{array}{l}\text { Std. } \\
\text { Dev. }\end{array}$ & Mean & $\begin{array}{l}\text { Std. } \\
\text { Dev. }\end{array}$ & Mean & $\begin{array}{l}\text { Std. } \\
\text { Dev. }\end{array}$ & Mean & $\begin{array}{l}\text { Std. } \\
\text { Dev. }\end{array}$ & Mean & $\begin{array}{l}\text { Std. } \\
\text { Dev. }\end{array}$ & Mean & $\begin{array}{l}\text { Std. } \\
\text { Dev. }\end{array}$ \\
\hline Value of total imports & 17.32 & 87.78 & 38.59 & 341.41 & 1.63 & 7.78 & 6.61 & 53.01 & 19.58 & 82.26 & 46.58 & 394.59 & 25.39 & 98.88 & 37.59 & 132.94 \\
\hline Average value of imports per country & 1.11 & 5.83 & 1.38 & 13.24 & 0.11 & 0.42 & 0.26 & 2.09 & 1.26 & 6.44 & 1.53 & 12.14 & 1.80 & 6.40 & 2.10 & 22.75 \\
\hline Number of countries & 13 & 9 & 6 & 7 & 12 & 8 & 8 & 8 & 13 & 9 & 6 & 6 & 14 & 9 & 6 & 6 \\
\hline Number of WTO countries & 12 & 8 & 6 & 6 & 11 & 7 & 8 & 8 & 12 & 8 & 6 & 6 & 13 & 8 & 6 & 5 \\
\hline Number of non-WTO countries & 1 & 1 & 0 & 1 & 1 & 1 & 0 & 1 & 1 & 1 & 0 & 1 & 1 & 1 & -1 & 1 \\
\hline Number of OECD countries & 9 & 6 & 3 & 3 & 8 & 5 & 3 & 4 & 9 & 6 & 3 & 3 & 10 & 6 & 3 & 3 \\
\hline Number of non-OECD countries & 4 & 4 & 3 & 5 & 4 & 3 & 5 & 6 & 4 & 4 & 3 & 4 & 4 & 3 & 3 & 3 \\
\hline Average value of imports per firm & 0.34 & 3.25 & 0.29 & 4.59 & 0.04 & 0.26 & 0.08 & 1.09 & 0.38 & 3.41 & 0.34 & 4.57 & 0.60 & 4.56 & 0.40 & 7.07 \\
\hline Number of firms & 104 & 229 & 127 & 394 & 57 & 172 & 68 & 315 & 112 & 244 & 135 & 417 & 135 & 210 & 176 & 386 \\
\hline Number of producers & 66 & 161 & 101 & 326 & 32 & 127 & 38 & 254 & 75 & 173 & 111 & 347 & 77 & 129 & 143 & 312 \\
\hline Number of state-owned producers & 16 & 34 & 0 & 16 & 8 & 19 & -1 & 10 & 16 & 35 & 0 & 16 & 27 & 42 & 2 & 23 \\
\hline Number of foreign-owned producers & 40 & 107 & 82 & 273 & 17 & 89 & 27 & 217 & 48 & 117 & 94 & 293 & 36 & 71 & 110 & 244 \\
\hline Number of domestic-private-owned producers & 1 & 2 & 26 & 64 & 1 & 1 & 17 & 48 & 1 & 2 & 26 & 65 & 1 & 2 & 40 & 73 \\
\hline Number of intermediaries & 38 & 72 & 26 & 74 & 25 & 47 & 30 & 69 & 37 & 74 & 24 & 74 & 58 & 86 & 33 & 79 \\
\hline Number of state-owned intermediaries & 33 & 63 & -6 & 26 & 21 & 41 & -1 & 16 & 33 & 65 & -8 & 27 & 52 & 76 & -9 & 31 \\
\hline $\begin{array}{l}\text { Number of foreign-owned intermediaries } \\
\text { Number of domestic-private-owned }\end{array}$ & 0 & 1 & 2 & 6 & 0 & 1 & 3 & 7 & 0 & 1 & 2 & 6 & 0 & 0 & 2 & 5 \\
\hline intermediaries & 0 & 1 & 33 & 72 & 0 & 1 & 30 & 64 & 0 & 1 & 31 & 73 & 0 & 1 & 44 & 73 \\
\hline
\end{tabular}

Notes: Values are expressed in USD millions. Source: Author's calculations using data on import transactions under ordinary trade regime from the database of Chinese Customs Trade Statistics (CCTS) managed by the General Administration of Customs of China. 
Table 2 - Tariff policy reforms in China over the 2000-2006 period: Tariff binding and Applied tariffs

\begin{tabular}{|c|c|c|c|c|c|c|c|}
\hline & 2000 & 2001 & 2002 & 2003 & 2004 & 2005 & 2006 \\
\hline \multicolumn{8}{|c|}{ Applied tariff } \\
\hline All goods & 0.162 & 0.151 & 0.118 & 0.108 & 0.099 & 0.095 & 0.095 \\
\hline Final goods & 0.252 & 0.229 & 0.195 & 0.177 & 0.159 & 0.150 & 0.150 \\
\hline Intermediate goods & 0.135 & 0.126 & 0.097 & 0.089 & 0.082 & 0.079 & 0.079 \\
\hline Capital goods & 0.152 & 0.147 & 0.102 & 0.092 & 0.086 & 0.085 & 0.085 \\
\hline \multicolumn{8}{|l|}{ Binding } \\
\hline All goods & 0 & 0 & 0.573 & 0.659 & 0.835 & 0.971 & 0.974 \\
\hline Final goods & 0 & 0 & 0.326 & 0.376 & 0.673 & 0.992 & 0.992 \\
\hline Intermediate goods & 0 & 0 & 0.660 & 0.727 & 0.865 & 0.962 & 0.967 \\
\hline Capital goods & 0 & 0 & 0.543 & 0.764 & 0.938 & 0.980 & 0.980 \\
\hline
\end{tabular}

Notes: Both applied tariff rates and the shares of product lines subject to binding are expressed in decimals. Source: Author's calculations using data on MFN applied tariffs from World Bank's WITS database, and bound tariff data are from WTO's Consolidated Tariff Schedules database. 
Table 3 - Product-level import changes from tariff binding: country-extensive and country-intensive margins

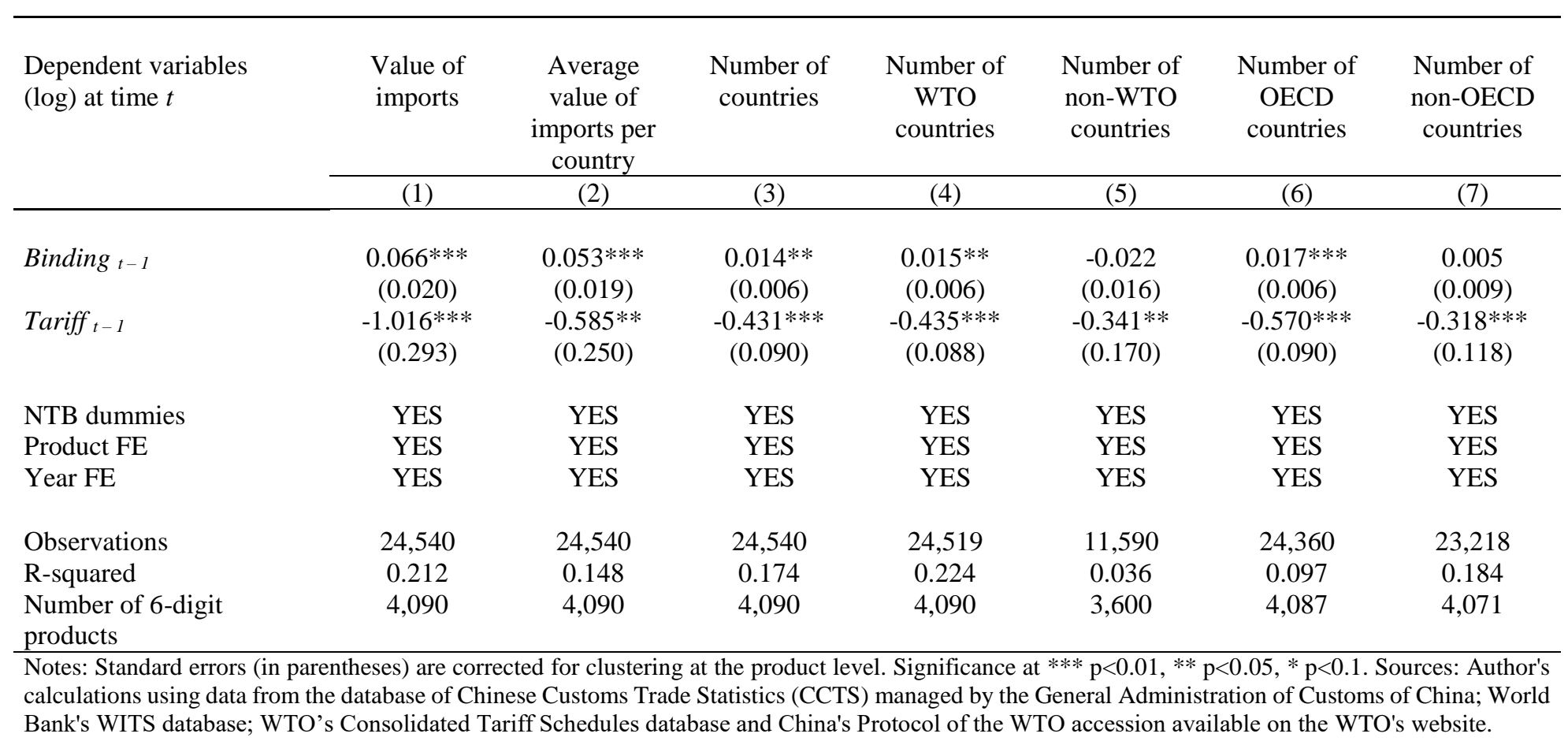


Table 4 - Country-extensive margins of imports and tariff binding: final, intermediate, and capital goods

\begin{tabular}{|c|c|c|c|c|c|c|c|}
\hline \multirow[t]{2}{*}{$\begin{array}{l}\text { Dependent variables } \\
(\log ) \text { at time } t\end{array}$} & Value of imports & $\begin{array}{c}\text { Average value } \\
\text { of imports } \\
\text { per country }\end{array}$ & $\begin{array}{c}\text { Number of } \\
\text { countries }\end{array}$ & $\begin{array}{l}\text { Number of } \\
\text { WTO } \\
\text { countries }\end{array}$ & $\begin{array}{c}\text { Number of } \\
\text { non-WTO } \\
\text { countries }\end{array}$ & $\begin{array}{l}\text { Number of } \\
\text { OECD } \\
\text { countries }\end{array}$ & $\begin{array}{c}\text { Number of } \\
\text { non-OECD } \\
\text { countries }\end{array}$ \\
\hline & $(1)$ & $(2)$ & (3) & $(6)$ & $(7)$ & $(4)$ & $(5)$ \\
\hline Binding $_{t-1}$ *Final good & $\begin{array}{c}0.089 * * * \\
(0.033)\end{array}$ & $\begin{array}{c}0.070 * * \\
(0.030)\end{array}$ & $\begin{array}{l}0.018 * \\
(0.011)\end{array}$ & $\begin{array}{c}0.014 \\
(0.011)\end{array}$ & $\begin{array}{c}0.023 \\
(0.024)\end{array}$ & $\begin{array}{c}0.015 \\
(0.011)\end{array}$ & $\begin{array}{c}0.023 \\
(0.015)\end{array}$ \\
\hline Binding $_{t-1} *$ Intermediate good & $\begin{array}{c}0.130 * * * \\
(0.024)\end{array}$ & $\begin{array}{c}0.102 * * * \\
(0.022)\end{array}$ & $\begin{array}{c}0.028 * * * \\
(0.008)\end{array}$ & $\begin{array}{c}0.031 * * * \\
(0.007)\end{array}$ & $\begin{array}{l}-0.026 \\
(0.018)\end{array}$ & $\begin{array}{c}0.031 * * * \\
(0.008)\end{array}$ & $\begin{array}{c}0.006 \\
(0.011)\end{array}$ \\
\hline Binding $_{t-1} *$ Capital good & $\begin{array}{c}-0.199 * * * \\
(0.035)\end{array}$ & $\begin{array}{l}-0.156 * * * \\
(0.032)\end{array}$ & $\begin{array}{c}-0.044 * * * \\
(0.011)\end{array}$ & $\begin{array}{c}-0.041 * * * \\
(0.011)\end{array}$ & $\begin{array}{l}-0.077 * * * \\
(0.027)\end{array}$ & $\begin{array}{l}-0.031 * * * \\
(0.011)\end{array}$ & $\begin{array}{l}-0.029 * \\
(0.016)\end{array}$ \\
\hline Tariff $_{t-1}$ & $\begin{array}{l}-1.093 * * * \\
(0.299)\end{array}$ & $\begin{array}{c}-0.643 * * \\
(0.253)\end{array}$ & $\begin{array}{l}-0.450 * * * \\
(0.092)\end{array}$ & $\begin{array}{c}-0.462 * * * \\
(0.090)\end{array}$ & $\begin{array}{l}-0.301^{*} \\
(0.170)\end{array}$ & $\begin{array}{l}-0.601 * * * \\
(0.092)\end{array}$ & $\begin{array}{c}-0.303 * * \\
(0.119)\end{array}$ \\
\hline NTB dummies & YES & YES & YES & YES & YES & YES & YES \\
\hline Product FE & YES & YES & YES & YES & YES & YES & YES \\
\hline Year FE & YES & YES & YES & YES & YES & YES & YES \\
\hline Observations & 24,492 & 24,492 & 24,492 & 24,471 & 11,566 & 24,312 & 23,175 \\
\hline R-squared & 0.218 & 0.153 & 0.176 & 0.226 & 0.038 & 0.099 & 0.185 \\
\hline Number of 6-digit products & 4,082 & 4,082 & 4,082 & 4,082 & 3,592 & 4,079 & 4,063 \\
\hline
\end{tabular}


Table 5 - Product-level imports changes from tariff binding: firm-extensive and firm-intensive margins

\begin{tabular}{|c|c|c|c|c|c|}
\hline \multirow[t]{2}{*}{$\begin{array}{l}\text { Dependent variables } \\
(\log ) \text { at time } t\end{array}$} & $\begin{array}{l}\text { Value of } \\
\text { imports }\end{array}$ & $\begin{array}{l}\text { Average value } \\
\text { of imports per } \\
\text { firm }\end{array}$ & $\begin{array}{l}\text { Number of } \\
\text { firms }\end{array}$ & $\begin{array}{l}\text { Number of } \\
\text { producers }\end{array}$ & $\begin{array}{c}\text { Number of } \\
\text { intermediaries }\end{array}$ \\
\hline & $(1)$ & $(2)$ & (3) & $(4)$ & $(5)$ \\
\hline Binding $_{t-1}$ & $\begin{array}{c}0.066 * * * \\
(0.020)\end{array}$ & $\begin{array}{c}0.037 * * \\
(0.017)\end{array}$ & $\begin{array}{c}0.030 * * * \\
(0.008)\end{array}$ & $\begin{array}{c}0.028 * * * \\
(0.009)\end{array}$ & $\begin{array}{c}0.022 * * \\
(0.010)\end{array}$ \\
\hline Tariff $_{t-1}$ & $\begin{array}{c}-1.016 * * * \\
(0.293)\end{array}$ & $\begin{array}{c}-0.495^{* *} \\
(0.221)\end{array}$ & $\begin{array}{c}-0.521 * * * \\
(0.155)\end{array}$ & $\begin{array}{c}-0.479 * * * \\
(0.147)\end{array}$ & $\begin{array}{c}-0.909 * * * \\
(0.192)\end{array}$ \\
\hline NTB dummies & YES & YES & YES & YES & YES \\
\hline Product FE & YES & YES & YES & YES & YES \\
\hline Year FE & YES & YES & YES & YES & YES \\
\hline Observations & 24,540 & 24,540 & 24,540 & 24,322 & 23,970 \\
\hline R-squared & 0.212 & 0.099 & 0.276 & 0.329 & 0.101 \\
\hline Number of 6-digit products & 4,090 & 4,090 & 4,090 & 4,089 & 4,089 \\
\hline
\end{tabular}


Table 6 - Firm-extensive margins of imports and tariff binding: producers versus intermediaries

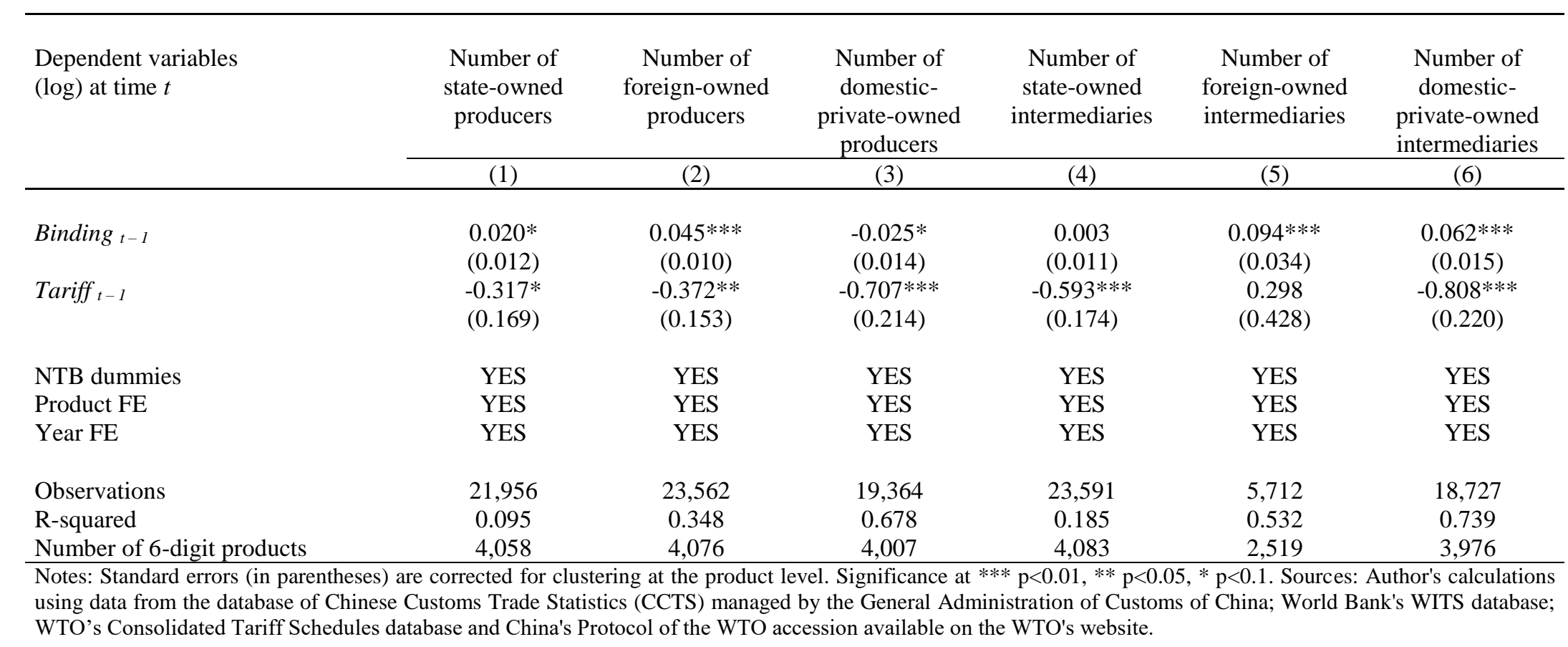


Table 7 - Firm-extensive margins of imports and tariff binding: final, intermediate, and capital goods

\begin{tabular}{|c|c|c|c|c|c|c|c|c|c|c|c|}
\hline & $\begin{array}{l}\text { Value of } \\
\text { imports }\end{array}$ & $\begin{array}{l}\text { Average value } \\
\text { of imports per } \\
\text { firm }\end{array}$ & $\begin{array}{c}\text { Number of } \\
\text { firms }\end{array}$ & $\begin{array}{l}\text { Number of } \\
\text { producers }\end{array}$ & $\begin{array}{c}\text { Number of } \\
\text { state-owned } \\
\text { producers }\end{array}$ & $\begin{array}{l}\text { Number of } \\
\text { foreign-owned } \\
\text { producers }\end{array}$ & $\begin{array}{c}\text { Number of } \\
\text { domestic- } \\
\text { private-owned } \\
\text { producers }\end{array}$ & $\begin{array}{c}\text { Number of } \\
\text { intermediaries }\end{array}$ & $\begin{array}{c}\text { Number of } \\
\text { state-owned } \\
\text { intermediaries }\end{array}$ & $\begin{array}{l}\text { Number of } \\
\text { foreign-owned } \\
\text { intermediaries }\end{array}$ & $\begin{array}{c}\begin{array}{c}\text { Number of } \\
\text { domestic- } \\
\text { private-owned } \\
\text { intermediaries }\end{array} \\
\end{array}$ \\
\hline VARIABLES & (1) & (2) & (3) & (4) & (5) & (6) & (7) & (8) & (9) & $(10)$ & (11) \\
\hline Binding $_{t-1} *$ Final good & $\begin{array}{c}0.089 * * * \\
(0.033)\end{array}$ & $\begin{array}{c}0.090 * * * \\
(0.028)\end{array}$ & $\begin{array}{l}-0.001 \\
(0.015)\end{array}$ & $\begin{array}{l}-0.016 \\
(0.017)\end{array}$ & $\begin{array}{c}-0.081 * * * \\
(0.020)\end{array}$ & $\begin{array}{c}0.005 \\
(0.019)\end{array}$ & $\begin{array}{l}-0.047 * \\
(0.024)\end{array}$ & $\begin{array}{c}0.053 * * * \\
(0.017)\end{array}$ & $\begin{array}{l}-0.014 \\
(0.017)\end{array}$ & $\begin{array}{l}0.115^{* *} \\
(0.057)\end{array}$ & $\begin{array}{c}0.023 \\
(0.024)\end{array}$ \\
\hline Binding $_{t-1} *$ Intermediate good & $\begin{array}{c}0.130 * * * \\
(0.024)\end{array}$ & $\begin{array}{c}0.064 * * * \\
(0.021)\end{array}$ & $\begin{array}{c}0.066^{* * * *} \\
(0.010)\end{array}$ & $\begin{array}{c}0.054^{* * * *} \\
(0.011)\end{array}$ & $\begin{array}{c}0.072 * * * \\
(0.014)\end{array}$ & $\begin{array}{l}0.030^{* *} * \\
(0.012)\end{array}$ & $\begin{array}{c}0.010 \\
(0.017)\end{array}$ & $\begin{array}{l}0.053^{* * *} * \\
(0.012)\end{array}$ & $\begin{array}{c}0.038 * * * \\
(0.013)\end{array}$ & $\begin{array}{c}0.058 \\
(0.039)\end{array}$ & $\begin{array}{l}0.102 * * * \\
(0.019)\end{array}$ \\
\hline Binding $_{t-1} *$ Capital good & $\begin{array}{c}-0.199 * * * \\
(0.035)\end{array}$ & $\begin{array}{l}-0.144 * * * * \\
(0.028)\end{array}$ & $\begin{array}{c}-0.055^{* * *} \\
(0.017)\end{array}$ & $\begin{array}{c}0.003 \\
(0.017)\end{array}$ & $\begin{array}{l}-0.017 \\
(0.021)\end{array}$ & $\begin{array}{c}0.159^{* * * *} \\
(0.019)\end{array}$ & $\begin{array}{c}-0.103 * * * * \\
(0.027)\end{array}$ & $\begin{array}{c}-0.136 * * * * \\
(0.019)\end{array}$ & $\begin{array}{l}-0.097^{* * * *} \\
(0.019)\end{array}$ & $\begin{array}{c}0.245 * * * \\
(0.071)\end{array}$ & $\begin{array}{l}-0.003 \\
(0.031)\end{array}$ \\
\hline Tariff $_{t-1}$ & $\begin{array}{c}-1.093 * * * \\
(0.299)\end{array}$ & $\begin{array}{c}-0.487^{* * *} \\
(0.221)\end{array}$ & $\begin{array}{c}-0.606 * * * \\
(0.163)\end{array}$ & $\begin{array}{c}-0.552 * * * \\
(0.153)\end{array}$ & $\begin{array}{c}-0.490^{* * * *} \\
(0.173)\end{array}$ & $\begin{array}{c}-0.359^{* * *} \\
(0.155)\end{array}$ & $\begin{array}{c}-0.795 * * * \\
(0.217)\end{array}$ & $\begin{array}{c}-0.943^{* * * *} \\
(0.200)\end{array}$ & $\begin{array}{c}-0.670^{* * * * *} \\
(0.182)\end{array}$ & $\begin{array}{c}0.427 \\
(0.438)\end{array}$ & $\begin{array}{c}-0.906 * * * * \\
(0.228)\end{array}$ \\
\hline NTB dummies & YES & YES & YES & YES & YES & YES & YES & YES & YES & YES & YES \\
\hline Product FE & YES & YES & YES & YES & YES & YES & YES & YES & YES & YES & YES \\
\hline Year FE & YES & YES & YES & YES & YES & YES & YES & YES & YES & YES & YES \\
\hline Observations & 24,492 & 24,492 & 24,492 & 24,274 & 21,914 & 23,531 & 19,339 & 23,924 & 23,545 & 5,706 & 18,713 \\
\hline R-squared & 0.218 & 0.103 & 0.280 & 0.332 & 0.100 & 0.351 & 0.679 & 0.107 & 0.188 & 0.534 & 0.740 \\
\hline Number of 6-digit products & 4,082 & 4,082 & 4,082 & 4,081 & 4,050 & 4,068 & 3,999 & 4,081 & 4,075 & 2,518 & 3,972 \\
\hline
\end{tabular}




\section{Appendix}

Table A.1 - Endogeneity of trade reforms

\begin{tabular}{|c|c|c|c|c|}
\hline \multirow[b]{3}{*}{ VARIABLES } & \multicolumn{2}{|c|}{ Change 2000-2006 } & \multicolumn{2}{|c|}{ Change 2000-2002 } \\
\hline & $\Delta$ Binding & $\Delta$ Tariff & $\triangle$ Binding & $\Delta$ Tariff \\
\hline & (1) & (2) & (3) & (4) \\
\hline \multirow[t]{2}{*}{ Import unit value (in log) } & 0.004 & 0.001 & 0.002 & 0.001 \\
\hline & $(0.004)$ & $(0.001)$ & $(0.006)$ & $(0.001)$ \\
\hline \multirow{2}{*}{ Foreign share of import firms } & $0.031 *$ & -0.008 & 0.074 & -0.007 \\
\hline & $(0.018)$ & $(0.012)$ & $(0.053)$ & $(0.008)$ \\
\hline \multirow[t]{2}{*}{ OECD share of source countries } & 0.007 & 0.018 & 0.015 & 0.021 \\
\hline & $(0.020)$ & $(0.016)$ & $(0.057)$ & $(0.014)$ \\
\hline \multirow[t]{2}{*}{ Intermediary share of import firms } & 0.011 & -0.010 & 0.035 & -0.004 \\
\hline & $(0.008)$ & $(0.009)$ & $(0.054)$ & $(0.006)$ \\
\hline \multirow[t]{2}{*}{ State importing } & -0.064 & $-0.159 * *$ & $-0.161 * *$ & $-0.097 * *$ \\
\hline & $(0.065)$ & $(0.070)$ & $(0.066)$ & $(0.048)$ \\
\hline \multirow[t]{2}{*}{ Trading rights restrictions } & 0.004 & -0.016 & 0.039 & -0.025 \\
\hline & $(0.015)$ & $(0.041)$ & $(0.142)$ & $(0.038)$ \\
\hline \multirow{2}{*}{ Elasticity of import substitution } & -0.008 & -0.001 & 0.001 & -0.000 \\
\hline & $(0.008)$ & $(0.002)$ & $(0.026)$ & $(0.002)$ \\
\hline \multirow{2}{*}{ Final good } & 0.152 & $-0.054 * *$ & 0.010 & $-0.031 * *$ \\
\hline & $(0.137)$ & $(0.025)$ & $(0.121)$ & $(0.015)$ \\
\hline \multirow[t]{2}{*}{ Intermediate good } & 0.133 & -0.021 & 0.168 & -0.015 \\
\hline & $(0.138)$ & $(0.025)$ & $(0.117)$ & $(0.015)$ \\
\hline \multirow[t]{2}{*}{ Capital good } & 0.142 & $-0.048 *$ & -0.034 & $-0.032 * *$ \\
\hline & $(0.140)$ & $(0.025)$ & $(0.119)$ & $(0.015)$ \\
\hline 2-digit Industry FE & YES & YES & YES & YES \\
\hline Observations & 4,039 & 4,039 & 4,039 & 4,039 \\
\hline R-squared & 0.075 & 0.443 & 0.429 & 0.308 \\
\hline
\end{tabular}


Table A.2 - Firm related margins of imports and tariff binding gap

\begin{tabular}{|c|c|c|c|c|c|c|c|c|c|}
\hline $\begin{array}{l}\text { Dependent variables } \\
(\log ) \text { at time } t\end{array}$ & $\begin{array}{l}\text { Value of } \\
\text { imports }\end{array}$ & $\begin{array}{l}\text { Average value } \\
\text { of imports per } \\
\text { firm }\end{array}$ & $\begin{array}{l}\text { Number of } \\
\text { firms }\end{array}$ & $\begin{array}{c}\text { Number of } \\
\text { state-owned } \\
\text { producers }\end{array}$ & $\begin{array}{l}\text { Number of } \\
\text { foreign-owned } \\
\text { producers }\end{array}$ & $\begin{array}{c}\text { Number of } \\
\text { domestic- } \\
\text { private-owned } \\
\text { producers }\end{array}$ & $\begin{array}{c}\text { Number of } \\
\text { state-owned } \\
\text { intermediaries }\end{array}$ & $\begin{array}{c}\text { Number of } \\
\text { foreign-owned } \\
\text { intermediaries }\end{array}$ & $\begin{array}{c}\begin{array}{c}\text { Number of } \\
\text { domestic- }\end{array} \\
\text { private-owned } \\
\text { intermediaries }\end{array}$ \\
\hline & $(1)$ & $(2)$ & (3) & $(4)$ & $(5)$ & (6) & $(7)$ & $(8)$ & $(9)$ \\
\hline Binding Gap $_{t-1}$ & $\begin{array}{c}0.066 * * * \\
(0.020)\end{array}$ & $\begin{array}{c}0.037 * * \\
(0.017)\end{array}$ & $\begin{array}{c}0.030 * * * \\
(0.008)\end{array}$ & $\begin{array}{l}0.020^{*} \\
(0.012)\end{array}$ & $\begin{array}{c}0.045 * * * \\
(0.010)\end{array}$ & $\begin{array}{l}-0.025^{*} \\
(0.014)\end{array}$ & $\begin{array}{c}0.003 \\
(0.011)\end{array}$ & $\begin{array}{c}0.094 * * * \\
(0.034)\end{array}$ & $\begin{array}{c}0.062 * * * \\
(0.015)\end{array}$ \\
\hline Tariff $_{t-1}$ & $\begin{array}{c}-1.016^{* * * *} \\
(0.293)\end{array}$ & $\begin{array}{c}-0.495 * * \\
(0.221)\end{array}$ & $\begin{array}{c}-0.521 * * * \\
(0.155)\end{array}$ & $\begin{array}{l}-0.316^{*} \\
(0.169)\end{array}$ & $\begin{array}{c}-0.372 * * \\
(0.153)\end{array}$ & $\begin{array}{c}-0.707 * * * \\
(0.214)\end{array}$ & $\begin{array}{c}-0.593 * * * \\
0.003\end{array}$ & $\begin{array}{c}0.298 \\
(0.428)\end{array}$ & $\begin{array}{c}-0.808 * * * \\
(0.220)\end{array}$ \\
\hline NTB dummies & YES & YES & YES & YES & YES & YES & YES & YES & YES \\
\hline Product FE & YES & YES & YES & YES & YES & YES & YES & YES & YES \\
\hline Year FE & YES & YES & YES & YES & YES & YES & YES & YES & YES \\
\hline Observations & 24,540 & 24,540 & 24,540 & 21,956 & 23,562 & 19,364 & 23,591 & 5,712 & 18,727 \\
\hline R-squared & 0.212 & 0.099 & 0.276 & 0.095 & 0.348 & 0.678 & 0.185 & 0.532 & 0.739 \\
\hline $\begin{array}{l}\text { Number of 6-digit } \\
\text { products }\end{array}$ & 4,090 & 4,090 & 4,090 & 4,058 & 4,076 & 4,007 & 4,083 & 2,519 & 3,976 \\
\hline
\end{tabular}


Table A.3 - Firm related margins of imports and tariff binding: Excluding foreign TPU effect

\begin{tabular}{|c|c|c|c|c|c|c|c|c|c|}
\hline $\begin{array}{l}\text { Dependent variables } \\
(\log ) \text { at time } t\end{array}$ & $\begin{array}{l}\text { Value of } \\
\text { imports }\end{array}$ & $\begin{array}{l}\text { Average value } \\
\text { of imports per } \\
\text { firm }\end{array}$ & $\begin{array}{l}\text { Number of } \\
\text { firms }\end{array}$ & $\begin{array}{c}\text { Number of } \\
\text { state-owned } \\
\text { producers }\end{array}$ & $\begin{array}{l}\text { Number of } \\
\text { foreign-owned } \\
\text { producers }\end{array}$ & $\begin{array}{c}\text { Number of } \\
\text { domestic- } \\
\text { private-owned } \\
\text { producers }\end{array}$ & $\begin{array}{c}\text { Number of } \\
\text { state-owned } \\
\text { intermediaries }\end{array}$ & $\begin{array}{c}\text { Number of } \\
\text { foreign-owned } \\
\text { intermediaries }\end{array}$ & $\begin{array}{c}\begin{array}{c}\text { Number of } \\
\text { domestic- }\end{array} \\
\text { private-owned } \\
\text { intermediaries }\end{array}$ \\
\hline & $(1)$ & $(2)$ & (3) & $(4)$ & $(5)$ & (6) & $(7)$ & $(8)$ & $(9)$ \\
\hline Binding $_{t-1}$ & $\begin{array}{c}0.091 * * \\
(0.038)\end{array}$ & $\begin{array}{c}0.071 * * \\
(0.035)\end{array}$ & $\begin{array}{l}0.020^{*} \\
(0.011)\end{array}$ & $\begin{array}{l}-0.011 \\
(0.017)\end{array}$ & $\begin{array}{c}0.074 * * * \\
(0.012)\end{array}$ & $\begin{array}{l}-0.009 \\
(0.016)\end{array}$ & $\begin{array}{c}0.012 \\
(0.018)\end{array}$ & $\begin{array}{c}0.050 \\
(0.040)\end{array}$ & $\begin{array}{l}-0.009 \\
(0.019)\end{array}$ \\
\hline Tariff $_{t-1}$ & $\begin{array}{c}-2.376 * * * \\
(0.472)\end{array}$ & $\begin{array}{c}-1.287 * * * \\
(0.371)\end{array}$ & $\begin{array}{c}-1.090 * * * \\
(0.192)\end{array}$ & $\begin{array}{c}0.002 \\
(0.231)\end{array}$ & $\begin{array}{c}-0.698 * * * \\
(0.169)\end{array}$ & $\begin{array}{c}-0.891 * * * \\
(0.274)\end{array}$ & $\begin{array}{l}0.310 * \\
(0.176)\end{array}$ & $\begin{array}{c}0.558 \\
(0.571)\end{array}$ & $\begin{array}{c}-1.073 * * * \\
(0.289)\end{array}$ \\
\hline NTB dummies & YES & YES & YES & YES & YES & YES & YES & YES & YES \\
\hline Product FE & YES & YES & YES & YES & YES & YES & YES & YES & YES \\
\hline Year FE & YES & YES & YES & YES & YES & YES & YES & YES & YES \\
\hline Observations & 23,089 & 23,089 & 23,089 & 13,172 & 21,160 & 15,692 & 11,319 & 4,074 & 13,121 \\
\hline R-squared & 0.148 & 0.050 & 0.332 & 0.097 & 0.152 & 0.600 & 0.031 & 0.491 & 0.584 \\
\hline $\begin{array}{l}\text { Number of 6-digit } \\
\text { products }\end{array}$ & 4,082 & 4,082 & 4,082 & 3,399 & 4,019 & 3,761 & 3,115 & 2,116 & 3,496 \\
\hline
\end{tabular}


Table A.4 - Firm related margins of imports and tariff binding: The role of import frequency

\begin{tabular}{|c|c|c|c|c|}
\hline $\begin{array}{l}\text { Dependent variables } \\
(\log ) \text { at time } t\end{array}$ & $\begin{array}{c}\text { Number of } \\
\text { producers }\end{array}$ & $\begin{array}{c}\text { Number of } \\
\text { state-owned } \\
\text { producers }\end{array}$ & $\begin{array}{l}\text { Number of } \\
\text { foreign- } \\
\text { owned } \\
\text { producers }\end{array}$ & $\begin{array}{c}\text { Number of } \\
\text { domestic- } \\
\text { private- } \\
\text { owned } \\
\text { producers }\end{array}$ \\
\hline & $(1)$ & (2) & (3) & $(4)$ \\
\hline Binding $_{t-1} *^{*}$ Final good & $\begin{array}{c}0.054 \\
(0.096)\end{array}$ & $\begin{array}{l}-0.066 \\
(0.120)\end{array}$ & $\begin{array}{l}-0.014 \\
(0.121)\end{array}$ & $\begin{array}{c}0.130 \\
(0.168)\end{array}$ \\
\hline Binding $_{t-1} *_{\text {Intermediate good }}$ & $\begin{array}{l}0.091 * \\
(0.051)\end{array}$ & $\begin{array}{c}0.029 \\
(0.059)\end{array}$ & $\begin{array}{c}0.010 \\
(0.055)\end{array}$ & $\begin{array}{c}-0.338 * * * \\
(0.086)\end{array}$ \\
\hline Binding $_{t-1} *$ Capital good & $\begin{array}{l}-0.114 \\
(0.117)\end{array}$ & $\begin{array}{c}-0.313^{* *} \\
(0.123)\end{array}$ & $\begin{array}{c}0.285^{* *} \\
(0.125)\end{array}$ & $\begin{array}{c}-0.894 * * * \\
(0.171)\end{array}$ \\
\hline Binding $_{t-1} *$ Final good $*$ Import frequency & $\begin{array}{l}-0.052 \\
(0.066)\end{array}$ & $\begin{array}{l}-0.010 \\
(0.088)\end{array}$ & $\begin{array}{c}0.014 \\
(0.086)\end{array}$ & $\begin{array}{l}-0.129 \\
(0.121)\end{array}$ \\
\hline Binding $_{t-1} *$ Intermediate good $*$ Import frequency & $\begin{array}{l}-0.024 \\
(0.031)\end{array}$ & $\begin{array}{c}0.027 \\
(0.035)\end{array}$ & $\begin{array}{c}0.012 \\
(0.034)\end{array}$ & $\begin{array}{c}0.221 * * * \\
(0.053)\end{array}$ \\
\hline Binding $_{t-1} *$ Capital good $*$ Import frequency & $\begin{array}{c}0.085 \\
(0.082)\end{array}$ & $\begin{array}{c}0.214 * * \\
(0.084)\end{array}$ & $\begin{array}{l}-0.091 \\
(0.088)\end{array}$ & $\begin{array}{l}0.570 * * * \\
(0.120)\end{array}$ \\
\hline Tariff $_{t-1}$ & $\begin{array}{l}-0.542 * * * \\
(0.153)\end{array}$ & $\begin{array}{c}-0.491 * * * \\
(0.175)\end{array}$ & $\begin{array}{c}-0.367 * * \\
(0.156)\end{array}$ & $\begin{array}{l}-0.867 * * * \\
(0.220)\end{array}$ \\
\hline NTB dummies & YES & YES & YES & YES \\
\hline Product FE & YES & YES & YES & YES \\
\hline Year FE & YES & YES & YES & YES \\
\hline Observations & 24,274 & 21,914 & 23,531 & 19,339 \\
\hline $\mathrm{R}$-squared & 0.332 & 0.100 & 0.352 & 0.680 \\
\hline Number of 6-digit products & 4,081 & 4,050 & 4,068 & 3,999 \\
\hline
\end{tabular}


Table A.5 - Firm related margins of imports' reaction to tariffs when tariffs are bound

\begin{tabular}{|c|c|c|c|c|c|c|c|c|c|}
\hline $\begin{array}{l}\text { Dependent variables } \\
(\log ) \text { at time } t\end{array}$ & $\begin{array}{l}\text { Value of } \\
\text { imports }\end{array}$ & $\begin{array}{l}\text { Average value } \\
\text { of imports per } \\
\text { firm }\end{array}$ & $\begin{array}{l}\text { Number of } \\
\text { firms }\end{array}$ & $\begin{array}{c}\text { Number of } \\
\text { state-owned } \\
\text { producers }\end{array}$ & $\begin{array}{l}\text { Number of } \\
\text { foreign-owned } \\
\text { producers }\end{array}$ & $\begin{array}{c}\text { Number of } \\
\text { domestic- } \\
\text { private-owned } \\
\text { producers }\end{array}$ & $\begin{array}{c}\text { Number of } \\
\text { state-owned } \\
\text { intermediaries }\end{array}$ & $\begin{array}{l}\text { Number of } \\
\text { foreign-owned } \\
\text { intermediaries }\end{array}$ & $\begin{array}{c}\text { Number of } \\
\text { domestic- } \\
\text { private-owned } \\
\text { intermediaries }\end{array}$ \\
\hline & $(1)$ & $(2)$ & (3) & (4) & $(5)$ & (6) & $(7)$ & $(8)$ & (9) \\
\hline Binding $_{t-1}$ & $\begin{array}{c}0.134 * * * \\
(0.032)\end{array}$ & $\begin{array}{l}0.048^{*} \\
(0.027)\end{array}$ & $\begin{array}{c}0.086 * * * \\
(0.014)\end{array}$ & $\begin{array}{c}0.126 * * * \\
(0.018)\end{array}$ & $\begin{array}{c}0.107 * * * \\
(0.016)\end{array}$ & $\begin{array}{c}0.036 \\
(0.023)\end{array}$ & $\begin{array}{c}0.059 * * * \\
(0.016)\end{array}$ & $\begin{array}{c}0.120 * * \\
(0.050)\end{array}$ & $\begin{array}{c}0.128 * * * \\
(0.025)\end{array}$ \\
\hline Tariff $_{t-1}$ & $\begin{array}{l}-1.001 * * * \\
(0.294)\end{array}$ & $\begin{array}{c}-0.492 * * \\
(0.222)\end{array}$ & $\begin{array}{c}-0.509 * * * \\
(0.153)\end{array}$ & $\begin{array}{l}-0.287^{*} \\
(0.171)\end{array}$ & $\begin{array}{c}-0.359 * * \\
(0.147)\end{array}$ & $\begin{array}{c}-0.672 * * * \\
(0.215)\end{array}$ & $\begin{array}{c}-0.576 * * * \\
(0.173)\end{array}$ & $\begin{array}{c}0.310 \\
(0.430)\end{array}$ & $\begin{array}{c}-0.763 * * * \\
(0.218)\end{array}$ \\
\hline Binding $_{t-1} *$ Tariff $_{t-1}$ & $\begin{array}{c}-0.702 * * * \\
(0.252)\end{array}$ & $\begin{array}{l}-0.122 \\
(0.210)\end{array}$ & $\begin{array}{c}-0.581 * * * \\
(0.118)\end{array}$ & $\begin{array}{c}-1.121 * * * \\
(0.143)\end{array}$ & $\begin{array}{c}-0.656^{* * *} \\
(0.130)\end{array}$ & $\begin{array}{c}-0.616^{* * *} \\
(0.187)\end{array}$ & $\begin{array}{c}-0.574 * * * \\
(0.129)\end{array}$ & $\begin{array}{l}-0.282 \\
(0.433)\end{array}$ & $\begin{array}{c}-0.664 * * * \\
(0.202)\end{array}$ \\
\hline NTB dummies & YES & YES & YES & YES & YES & YES & YES & YES & YES \\
\hline Product FE & YES & YES & YES & YES & YES & YES & YES & YES & YES \\
\hline Year FE & YES & YES & YES & YES & YES & YES & YES & YES & YES \\
\hline Observations & 24,540 & 24,540 & 24,540 & 21,956 & 23,562 & 19,364 & 23,591 & 5,712 & 18,727 \\
\hline R-squared & 0.213 & 0.099 & 0.278 & 0.101 & 0.350 & 0.679 & 0.186 & 0.532 & 0.740 \\
\hline $\begin{array}{l}\text { Number of 6-digit } \\
\text { products }\end{array}$ & 4,090 & 4,090 & 4,090 & 4,058 & 4,076 & 4,007 & 4,083 & 2,519 & 3,976 \\
\hline
\end{tabular}


Table A.6 - Firm related margins of imports and tariff binding: processing imports

\begin{tabular}{|c|c|c|c|c|c|c|c|c|c|}
\hline $\begin{array}{l}\text { Dependent variables } \\
(\log ) \text { at time } t\end{array}$ & $\begin{array}{l}\text { Value of } \\
\text { imports }\end{array}$ & $\begin{array}{l}\text { Average value } \\
\text { of imports per } \\
\text { firm }\end{array}$ & $\begin{array}{l}\text { Number of } \\
\text { firms }\end{array}$ & $\begin{array}{c}\text { Number of } \\
\text { state-owned } \\
\text { producers }\end{array}$ & $\begin{array}{l}\text { Number of } \\
\text { foreign-owned } \\
\text { producers }\end{array}$ & $\begin{array}{c}\text { Number of } \\
\text { domestic- } \\
\text { private-owned } \\
\text { producers }\end{array}$ & $\begin{array}{c}\text { Number of } \\
\text { state-owned } \\
\text { intermediaries }\end{array}$ & $\begin{array}{c}\text { Number of } \\
\text { foreign-owned } \\
\text { intermediaries }\end{array}$ & $\begin{array}{c}\begin{array}{c}\text { Number of } \\
\text { domestic- } \\
\text { private-owned } \\
\text { intermediaries }\end{array} \\
\end{array}$ \\
\hline & $(1)$ & $(2)$ & (3) & $(4)$ & $(5)$ & $(6)$ & $(7)$ & $(8)$ & (9) \\
\hline Binding $_{t-1}$ & $\begin{array}{l}-0.036 \\
(0.028)\end{array}$ & $\begin{array}{l}-0.026 \\
(0.026)\end{array}$ & $\begin{array}{l}-0.010 \\
(0.009)\end{array}$ & $\begin{array}{c}0.005 \\
(0.011)\end{array}$ & $\begin{array}{l}-0.005 \\
(0.009)\end{array}$ & $\begin{array}{c}-0.105^{* * *} \\
(0.022)\end{array}$ & $\begin{array}{c}0.001 \\
(0.012)\end{array}$ & $\begin{array}{l}-0.052 \\
(0.039)\end{array}$ & $\begin{array}{c}-0.066 * * \\
(0.026)\end{array}$ \\
\hline Tariff $_{t-1}$ & $\begin{array}{c}1.267 * * * \\
(0.393)\end{array}$ & $\begin{array}{c}1.637 * * * \\
(0.343)\end{array}$ & $\begin{array}{c}-0.370^{* * *} \\
(0.131)\end{array}$ & $\begin{array}{c}0.360 * * \\
(0.145)\end{array}$ & $\begin{array}{c}-0.339 * * \\
(0.132)\end{array}$ & $\begin{array}{c}-2.108 * * * \\
(0.409)\end{array}$ & $\begin{array}{c}0.482 * * * \\
(0.173)\end{array}$ & $\begin{array}{l}-0.473^{*} \\
(0.278)\end{array}$ & $\begin{array}{c}-3.271 * * * \\
(0.598)\end{array}$ \\
\hline NTB dummies & YES & YES & YES & YES & YES & YES & YES & YES & YES \\
\hline Product FE & YES & YES & YES & YES & YES & YES & YES & YES & YES \\
\hline Year FE & YES & YES & YES & YES & YES & YES & YES & YES & YES \\
\hline Observations & 21,888 & 21,888 & 21,888 & 16,886 & 21,088 & 9,273 & 17,165 & 1,079 & 8,446 \\
\hline R-squared & 0.055 & 0.062 & 0.006 & 0.092 & 0.022 & 0.589 & 0.321 & 0.028 & 0.668 \\
\hline $\begin{array}{l}\text { Number of 6-digit } \\
\text { products }\end{array}$ & 3,923 & 3,923 & 3,923 & 3,395 & 3,837 & 2,603 & 3,416 & 458 & 2,481 \\
\hline
\end{tabular}


Table A.7 - Firm related margins of imports and tariff binding: Country/product level analysis

\begin{tabular}{|c|c|c|c|c|c|c|c|c|c|}
\hline $\begin{array}{l}\text { Dependent variables } \\
(\log ) \text { at time } t\end{array}$ & $\begin{array}{l}\text { Value of } \\
\text { imports }\end{array}$ & $\begin{array}{l}\text { Average value } \\
\text { of imports per } \\
\text { firm }\end{array}$ & $\begin{array}{l}\text { Number of } \\
\text { firms }\end{array}$ & $\begin{array}{l}\text { Number of } \\
\text { state-owned } \\
\text { producers }\end{array}$ & $\begin{array}{l}\text { Number of } \\
\text { foreign-owned } \\
\text { producers }\end{array}$ & $\begin{array}{c}\text { Number of } \\
\text { domestic- } \\
\text { private-owned } \\
\text { producers }\end{array}$ & $\begin{array}{c}\text { Number of } \\
\text { state-owned } \\
\text { intermediaries }\end{array}$ & $\begin{array}{l}\text { Number of } \\
\text { foreign-owned } \\
\text { intermediaries }\end{array}$ & $\begin{array}{c}\begin{array}{c}\text { Number of } \\
\text { domestic- } \\
\text { private-owned } \\
\text { intermediaries }\end{array}\end{array}$ \\
\hline & $(1)$ & (2) & (3) & (4) & $(5)$ & $(6)$ & $(7)$ & $(8)$ & (9) \\
\hline Binding $_{t-1}$ & $\begin{array}{c}0.007 \\
(0.016)\end{array}$ & $\begin{array}{l}-0.006 \\
(0.013)\end{array}$ & $\begin{array}{l}0.013^{*} \\
(0.007)\end{array}$ & $\begin{array}{c}0.020 * * \\
(0.008)\end{array}$ & $\begin{array}{c}0.038 * * * \\
(0.007)\end{array}$ & $\begin{array}{l}-0.004 \\
(0.010)\end{array}$ & $\begin{array}{l}-0.008 \\
(0.007)\end{array}$ & $\begin{array}{c}0.087 * * * \\
(0.030)\end{array}$ & $\begin{array}{c}0.050 * * * \\
(0.011)\end{array}$ \\
\hline Tariff $_{t-1}$ & $\begin{array}{c}-0.520 * * \\
(0.233)\end{array}$ & $\begin{array}{l}-0.158 \\
(0.186)\end{array}$ & $\begin{array}{c}-0.362 * * * \\
(0.128)\end{array}$ & $\begin{array}{l}-0.027 \\
(0.127)\end{array}$ & $\begin{array}{l}-0.113 \\
(0.123)\end{array}$ & $\begin{array}{c}0.083 \\
(0.212)\end{array}$ & $\begin{array}{c}-0.322 * * * \\
(0.119)\end{array}$ & $\begin{array}{c}0.691 * * \\
(0.347)\end{array}$ & $\begin{array}{l}-0.159 \\
(0.227)\end{array}$ \\
\hline NTB dummies & YES & YES & YES & YES & YES & YES & YES & YES & YES \\
\hline Country/Product FE & YES & YES & YES & YES & YES & YES & YES & YES & YES \\
\hline Year FE & YES & YES & YES & YES & YES & YES & YES & YES & YES \\
\hline Observations & 312,296 & 312,296 & 312,297 & 277,955 & 149,604 & 229,823 & 208,766 & 13,815 & 121,790 \\
\hline R-squared & 0.068 & 0.030 & 0.114 & 0.155 & 0.029 & 0.201 & 0.050 & 0.369 & 0.434 \\
\hline $\begin{array}{l}\text { Number of 6-digit } \\
\text { products }\end{array}$ & 78,118 & 78,118 & 78,118 & 71,630 & 46,662 & 61,596 & 58,638 & 9,855 & 44,848 \\
\hline
\end{tabular}


Table A.8 - Probability of importing and tariff binding: Firm/product(/country) level analysis

\begin{tabular}{|c|c|c|c|c|c|c|c|c|}
\hline \multirow{2}{*}{$\begin{array}{l}\text { Dependent variable: } \\
\text { Import dummy at time } t\end{array}$} & \multicolumn{4}{|c|}{ Firm/Product level analysis } & \multicolumn{4}{|c|}{ Firm/Product/Country level analysis } \\
\hline & $(1)$ & (2) & (3) & (4) & $(5)$ & (6) & (7) & $(8)$ \\
\hline Binding $_{t-1}$ & $\begin{array}{c}0.005^{* * * *} \\
(0.001)\end{array}$ & $\begin{array}{l}0.012 * * * \\
(0.003)\end{array}$ & $\begin{array}{c}0.005 * * * \\
(0.001)\end{array}$ & $\begin{array}{c}0.005 * * * \\
(0.001)\end{array}$ & $\begin{array}{c}0.006 * * * \\
(0.001)\end{array}$ & $\begin{array}{c}0.012 * * * \\
(0.003)\end{array}$ & $\begin{array}{c}0.006 * * * \\
(0.001)\end{array}$ & $\begin{array}{c}0.006 * * * \\
(0.001)\end{array}$ \\
\hline Tariff $_{t-1}$ & $\begin{array}{l}-0.013 \\
(0.028)\end{array}$ & $\begin{array}{c}0.008 \\
(0.029)\end{array}$ & $\begin{array}{l}-0.018 \\
(0.025)\end{array}$ & $\begin{array}{l}-0.018 \\
(0.025)\end{array}$ & $\begin{array}{l}-0.020 \\
(0.027)\end{array}$ & $\begin{array}{l}-0.001 \\
(0.029)\end{array}$ & $\begin{array}{l}-0.022 \\
(0.026)\end{array}$ & $\begin{array}{l}-0.022 \\
(0.026)\end{array}$ \\
\hline Binding $_{t-1} *$ Tariff $_{t-1}$ & & $\begin{array}{c}-0.088 * * * \\
(0.028)\end{array}$ & & & & $\begin{array}{c}-0.078 * * \\
(0.031)\end{array}$ & & \\
\hline Import dummy $_{t-1}$ & & & $\begin{array}{c}0.106 * * * \\
(0.003)\end{array}$ & $\begin{array}{c}0.106 * * * \\
(0.003)\end{array}$ & & & $\begin{array}{c}0.061 * * * \\
(0.003)\end{array}$ & $\begin{array}{c}0.061 * * * \\
(0.003)\end{array}$ \\
\hline Export dummy $_{t-1}$ & & & & $\begin{array}{l}-0.006 \\
(0.004)\end{array}$ & & & & $\begin{array}{l}-0.009^{*} \\
(0.005)\end{array}$ \\
\hline Import dummy $_{t-1} *$ Export dummy $_{t-1}$ & & & & $\begin{array}{c}0.013 \\
(0.016)\end{array}$ & & & & $\begin{array}{l}0.029 * \\
(0.016)\end{array}$ \\
\hline NTB dummies & YES & YES & YES & YES & YES & YES & YES & YES \\
\hline Firm/Year FE & YES & YES & YES & YES & YES & YES & YES & YES \\
\hline Product FE & YES & YES & YES & YES & NO & NO & NO & NO \\
\hline Country/Product FE & NO & NO & NO & NO & YES & YES & YES & YES \\
\hline Country/Year FE & NO & NO & NO & NO & YES & YES & YES & YES \\
\hline Observations & $13,300,679$ & $13,300,679$ & $13,300,679$ & $13,300,679$ & $19,011,547$ & $19,011,547$ & $19,011,547$ & $19,011,547$ \\
\hline R-squared & 0.316 & 0.316 & 0.323 & 0.323 & 0.285 & 0.285 & 0.287 & 0.287 \\
\hline
\end{tabular}

- Stes: Standard errors (in parentheses) are corrected for clustering at the product level. Significance at $* * * \mathrm{p}<0.01 * * \mathrm{p}<0.05 *$, $\mathrm{p}<0.1$. Sources: Author's calculations using dat

from the database of Chinese Customs Trade Statistics (CCTS) managed by the General Administration of Customs of China; World Bank's WITS database; WTO's Consolidated Tariff Schedules database and China's Protocol of the WTO accession available on the WTO's website. 